\title{
Preliminary Evaluation of Driver Fuel Plates and Reduced Sodium Temperature to Increase Fast Test Reactor Experimental Neutron Irradiation Capabilities
}

\section{November 2020}

Gilles Youinou

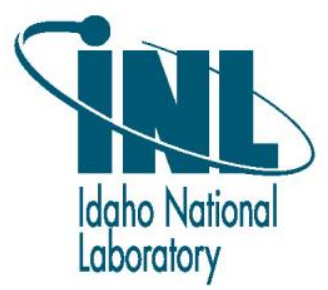


Page intentionally left blank 


\title{
Preliminary Evaluation of Driver Fuel Plates and Reduced Sodium Temperature to Increase Fast Test Reactor Neutron Irradiation Capabilities
}

\author{
Gilles Youinou
}

November 2020

\author{
Idaho National Laboratory \\ Nuclear Science \& Technology Directorate \\ Reactor Systems Design \& Analysis Division \\ Idaho Falls, Idaho 83415
}

http://www.inl.gov

Prepared for the

U.S. Department of Energy

Office of Nuclear Energy

Under DOE Idaho Operations Office

Contract DE-AC07-05ID14517 


\section{DISCLAIMER}

This information was prepared as an account of work sponsored by an agency of the U.S. Government. Neither the U.S. Government nor any agency thereof, nor any of their employees, makes any warranty, expressed or implied, or assumes any legal liability or responsibility for the accuracy, completeness, or usefulness, of any information, apparatus, product, or process disclosed, or represents that its use would not infringe privately owned rights. References herein to any specific commercial product, process, or service by trade name, trademark, manufacturer, or otherwise, does not necessarily constitute or imply its endorsement, recommendation, or favoring by the U.S. Government or any agency thereof. The views and opinions of authors expressed herein do not necessarily state or reflect those of the U.S. Government or any agency thereof. 


\section{EXECUTIVE SUMMARY}

All sodium-cooled fast test reactors operated so far have used essentially the same fuel geometrical arrangement, namely cylindrical fuel pins assembled into a triangular array in hexagonal fuel assemblies. Fuel compositions and dimensions may vary but the overall geometrical pattern remains identical. Furthermore, most sodium-cooled reactors have operated, and still operate, with core-average inlet and outlet sodium temperatures of $350-400^{\circ} \mathrm{C}$ and $500-550^{\circ} \mathrm{C}$, respectively.

The present preliminary study revisits the standard fuel assembly geometry as well as operating temperatures to evaluate the potential impact on fast test reactor neutron irradiation capabilities. The reference fuel is U-20Pu10Zr. Pin (reference) and plate geometries are considered together with two sets of core-average sodium inlet/outlet temperatures: $350 / 500^{\circ} \mathrm{C}$ (reference) and $200 / 400^{\circ} \mathrm{C}$. More prototypic environments could be obtained inside ad hoc irradiation testing vehicles that are independent from the reactor primary coolant.

Everything else being the same, fuel temperature is significantly lower in plates than in pins. Therefore, plates could in principle accommodate a higher plutonium content, thus, reducing the level of uranium enrichment needed or allowing the use of lower quality plutonium ( $\mathrm{U}-\mathrm{xPu}-10 \mathrm{Zr}$ thermal conductivity and solidus temperature decrease as $\mathrm{x}$ increases, hence, necessitating additional thermal margins).

For the reference pin configuration, lowering the inlet/outlet sodium temperatures from the reference $350 / 500^{\circ} \mathrm{C}$ down to $200 / 400^{\circ} \mathrm{C}$ provides additional thermal margins that can be used to increase the peak fast flux from about $4.4 \times 10^{15} \mathrm{n} / \mathrm{cm}^{2}$-s to $6.1 \times 10^{15} \mathrm{n} / \mathrm{cm}^{2}$-s for the same core power of $300 \mathrm{MW}$. Assuming 300 equivalent full-power days (EFPD) of operation per calendar year, a (steel) test article could accumulate up to 80 displacements per atom (dpa) per year. The use of fuel plates provides even greater thermal margins which may allow the peak fast flux to reach values as high as $7.9 \times 10^{15} \mathrm{n} / \mathrm{cm}^{2}$-s for both sets of inlet/outlet temperatures. In this environment, a test article could accumulate up to $100 \mathrm{dpa} /$ year assuming $300 \mathrm{EFPD} / y e a r$, greatly accelerating irradiation testing.

Enabling a fast test reactor to operate over a wide range of inlet/outlet temperatures could add significant flexibility to its neutron irradiation capabilities. Steel present in the driver fuel assemblies is not expected to accumulate more than 100 dpa over its lifetime. Hence, steel alloys that are not suited for very high dpa but can operate over a wide range of temperatures would be appropriate for this application.

Finally, because pin and plate assemblies fit on the same grid plate, a fast test reactor could in principle start-up with standard fuel pin assemblies and, later on, move to a plate-type Mark-II fuel to further increase its neutron irradiation capabilities while potentially reducing the level of uranium enrichment needed. 


\section{CONTENTS}

1. INTRODUCTION AND OBJECTIVE—_ 1

2. FUEL ASSEMBLY DESCRIPTIONS—— 1

3. SODIUM INLET/OUTLET TEMPERATURES- 4

4. CRITICAL COOLANT VELOCITY FOR FLAT PLATES_— 4

5. CORE PERFORMANCE PRELIMINARY EVALUATION——

5.1 Fuel and Cladding Maximum Allowable Nominal Temperature-_ 5

5.2 Medium-Grade Fuel—_ 5

5.3 High-Grade Fuel——

5.4 Super-High-Grade Fuel—_

6. CONCLUSIONS—_ 11

7. REFERENCES — 12

APPENDIX A. PRELIMINARY ESTIMATION OF THE FISSION GAS PRESSURE IN THE PLENUM- 13

APPENDIX B. PRELIMINARY ESTIMATION OF THE IMPACT OF SPACERS ON PLATE DEFORMATION DUE TO FISSION GAS PRESSURIZATION__ 14 


\section{FIGURES}

Figure 1. Radial cross-section of the reference hexagonal 271-fuel-pin fuel assembly (a), of a hexagonal fuel assembly containing $3 \times 11$ flat plates (b) and of a cylindrical fuel as-

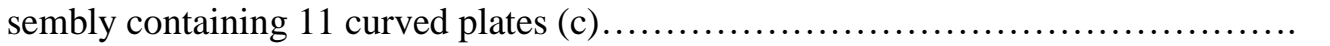

Figure 2. Illustration of cylindrical fuel assemblies located on a grid plate designed for hexagonal fuel assemblies.........................................................

Figure 3. Peak pin linear power axial distribution (left) and fuel centerline temperature (right) for sodium inlet/outlet temperatures $=350 / 550^{\circ} \mathrm{C}$ and $\mathrm{U}-20 \mathrm{Pu}-10 \mathrm{Zr}$ thermal conduc-

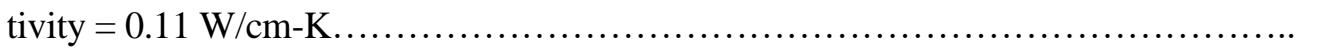

Figure 4. Example of 300-MW medium-grade-fuel core configuration - 66 driver fuel assem-

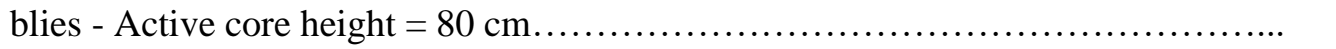

Figure 5. Example of 215-MW high-grade-fuel core configuration - 46 driver fuel assemblies

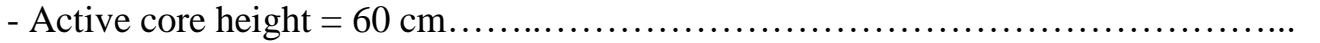

Figure 6. Example of 145-MW super-high-grade-fuel core configuration - 29 driver fuel as-

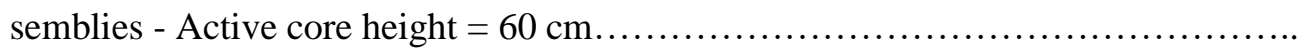

\section{TABLES}

Table 1. Fuel assemblies using fuel pins and fuel plates and characterized by similar volume fractions.

Table 2. Peak assembly thermal hydraulics characteristics for 66 fuel assembly 300-MW core configurations using pins or plates. Medium-grade fuel....

Table 3. Peak assembly thermal hydraulics characteristics for 46 fuel assembly 215-MW core configurations using pins or plates. High-grade fuel.

Table 4. Peak assembly thermal hydraulics characteristics for 46 fuel assembly 300-MW core configurations using pins or plates. High-grade fuel.

Table 5. Peak assembly thermal hydraulics characteristics for 29 fuel assembly 145-MW core configurations using pins or plates. Super-high-grade fuel.

Table 6. Peak assembly thermal hydraulics characteristics for a 29 fuel assembly 300-MW core configuration using plates. Super-high-grade fuel. 


\section{ACKNOWLEDGMENTS}

The author gratefully acknowledges the technical peer reviews provided by Dr. Douglas L. Porter, Dr. Samuel E. Bays, and Dr. Carlo Parisi, as well as the tech editing provided by Mrs. Alexandria N. Madden. 


\section{INTRODUCTION AND OBJECTIVE}

All sodium-cooled fast test reactors built and operated throughout the world so far have used essentially the same fuel geometrical arrangement, namely cylindrical fuel pins assembled into a triangular array in hexagonal fuel assemblies. Fuel compositions and dimensions may vary but the overall geometrical pattern remains identical.

A previous trade study [INL/EXT-20-57186] focused on sodium-cooled fast test reactors using metallic fuel (mainly $\mathrm{U}-20 \mathrm{Pu}-10 \mathrm{Zr}$ ). The main objective was to estimate the minimum number of fuel assemblies, core power, and peak fast neutron flux $(>0.1 \mathrm{MeV})$, given a set of design variables and requirements. The trade study assumed a standard fuel geometrical arrangement - cylindrical fuel pins assembled into a triangular array in hexagonal fuel assemblies - as well as standard operating temperatures, i.e., core-average sodium inlet and outlet temperatures of $350^{\circ} \mathrm{C}$ and $500^{\circ} \mathrm{C}$, respectively.

Using this previous study as a reference, the present study revisits the standard fuel assembly geometry as well as the operating temperatures. U-20Pu-10Zr driver fuel plates are considered as well as two sets of core-average sodium inlet/outlet temperatures $\left(350 / 500^{\circ} \mathrm{C}\right.$ and $\left.200 / 400^{\circ} \mathrm{C}\right)$. The sodium-cooled fast test reactor of interest here should reach a peak fast flux that is as high as possible and the core thermal power should not exceed $300 \mathrm{MW}$.

\section{FUEL ASSEMBLY DESCRIPTIONS}

The reference fuel assembly considered for this evaluation is one of the fuel assemblies analyzed in [INL/EXT-2057186]. It contains $2715.6-\mathrm{mm}$-diameter fuel pins arranged in a hexagonal 0.3 -cm-thick steel duct with an external flat-to-flat dimension of $11.7 \mathrm{~cm}$ (see Figure 1a, Table 1). Two active fuel heights were considered: $60 \mathrm{~cm}$ and 80 $\mathrm{cm}$. Assumed peak burnup is $10 \%$ corresponding to $3.1 \times 10^{21}$ fissions $/ \mathrm{cm}^{3}$. This combination \{pin diameter - cladding thickness - pin length $\}$ is within the Fast Flux Test Facility (FFTF) experience. With a sealed fission gas plenum of the same length located on top of the fuel column (i.e., at the outlet), the pin internal pressure reaches a typical maximum nominal value (i.e., w/o uncertainties) of about $5 \mathrm{MPa}$ during normal operation assuming a peak sodium outlet temperature of $550^{\circ} \mathrm{C}$ (see Appendix A).

a-

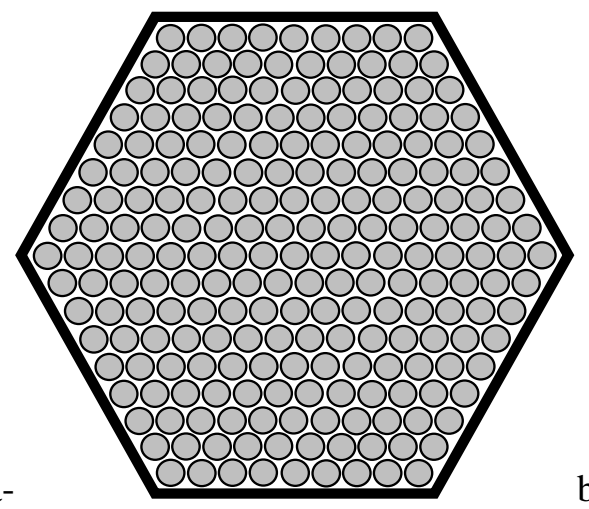

b-

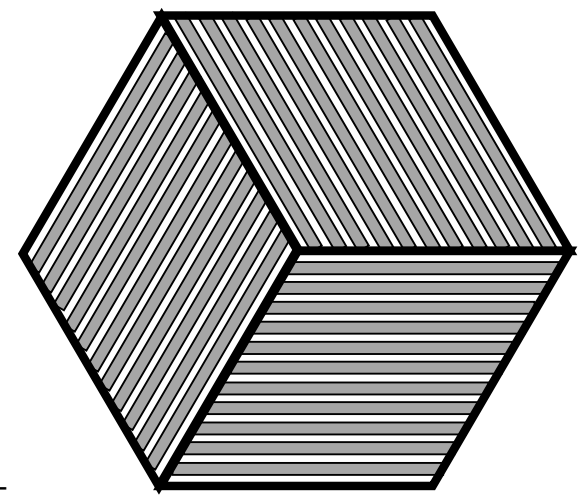

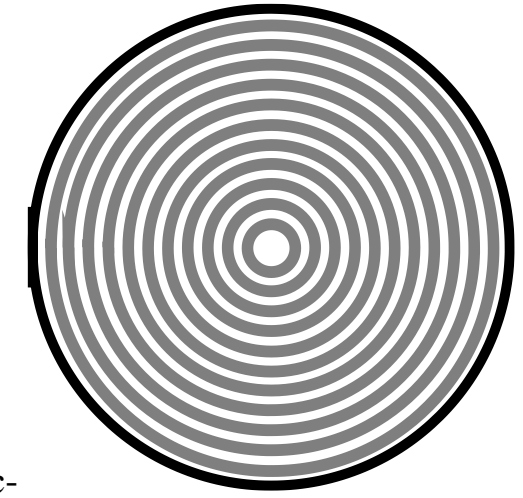

Figure 1. (a) Radial cross-section of the reference hexagonal 271-fuel-pin fuel assembly, (b) of a hexagonal fuel assembly containing $3 \times 11$ flat plates, and (c) and of a cylindrical fuel assembly containing 11 curved plates.

As a bounding pin configuration, a fuel assembly containing 397 4.6-mm-diameter fuel pins was also considered. For this configuration, fuel pin diameter and cladding thickness are close to those of the EBR-II Mark II fuel [Lahm, 1993]. Pins are however significantly longer than EBR-II's (120-160 cm vs. $61 \mathrm{~cm})$. Furthermore, 397-pin assemblies have never been used; consequently, when compared to the 271-pin assemblies, more work would probably be necessary to confirm their feasibility.

Two preliminary conceptual designs of fuel plate assemblies containing steel-clad U-20Pu-10Zr fuel plates are also illustrated in Figure 1b-c. The plate dimensions are chosen so that these assemblies have the same fuel volume fraction (and, consequently, the same fuel mass) as the reference fuel assembly using pins. Sodium flow areas are also similar. Cladding thickness is assumed to be the same as that of the reference fuel rods. Though not 
represented on Figure 1b-c, coolant channels may include spacers to minimize the probability of plate deformation leading to flow restrictions. It is noteworthy that these plate assemblies could fit on the same grid plate as the reference assemblies. There is currently no experience with these fuel geometries in a sodium-cooled fast reactor environment and, consequently, confirming their practicality would need significant work.

Table 1 presents the dimensions corresponding to each fuel assembly geometry. It is important to remark that the irradiated fuel plate meat thicknesses (2.4-2.5 mm) are significantly smaller than the fuel pin meat diameters (4.0$4.8 \mathrm{~mm}$ ). As will be shown in Section 5, everything else being the same, this difference leads to fuel temperatures being significantly lower in plates than in pins. $\frac{1}{}$ As a consequence, plates could, in principle, accommodate a higher plutonium content, thus, reducing the level of uranium enrichment needed or allowing the use of lower quality plutonium ( $\mathrm{U}-\mathrm{xPu}-10 \mathrm{Zr}$ thermal conductivity and solidus temperature decrease as $\mathrm{x}$ increases, hence, necessitating additional thermal margins).

Table 1. Fuel assemblies using fuel pins and fuel plates and characterized by similar volume fractions. Fuel smeared density factor is $75 \%$.

\begin{tabular}{|c|c|c|c|c|c|}
\hline \multicolumn{2}{|l|}{ Identifier } & B271 & B397 & $\mathrm{J} 11$ & K11 \\
\hline \multicolumn{2}{|l|}{ Geometry } & $\begin{array}{c}\text { Rods/Hex } \\
\text { Fig.1a }\end{array}$ & $\begin{array}{c}\text { Rods/Hex } \\
-\end{array}$ & $\begin{array}{l}\text { Plates/Hex } \\
\text { Fig.1b }\end{array}$ & $\begin{array}{c}\text { Plates/Cyl } \\
\text { Fig.1c } \\
\end{array}$ \\
\hline \multicolumn{2}{|l|}{ Assembly pitch $(\mathrm{cm})$} & 12.0 & 12.0 & 12.0 & 12.0 \\
\hline \multicolumn{2}{|c|}{ Gap between assemblies $(\mathrm{cm})$} & 0.3 & 0.3 & 0.3 & 0.3 \\
\hline \multicolumn{2}{|c|}{ Duct outside flat-to-flat or diameter $(\mathrm{cm})$} & 11.7 & 11.7 & 11.7 & 11.7 \\
\hline \multicolumn{2}{|l|}{ Duct thickness $(\mathrm{cm})$} & 0.3 & 0.3 & 0.3 & 0.3 \\
\hline \multicolumn{2}{|c|}{ Duct inside flat-to-flat or diameter $(\mathrm{cm})$} & 11.1 & 11.1 & 11.1 & 11.1 \\
\hline \multicolumn{2}{|c|}{ \# Rods / \# Plates per assembly } & 271 & 397 & $3 \times 11$ & $11^{\mathrm{c}}$ \\
\hline \multicolumn{2}{|c|}{ Pin outer diameter / Plate thickness $(\mathrm{cm})$} & 0.560 & 0.459 & 0.318 & 0.324 \\
\hline \multicolumn{2}{|l|}{ Plate width $(\mathrm{cm})$} & - & - & 6.235 & - \\
\hline \multicolumn{2}{|c|}{ Steel cladding thickness $(\mathrm{cm})$} & 0.039 & $0.0305^{\mathrm{b}}$ & 0.039 & 0.039 \\
\hline \multicolumn{2}{|c|}{ Fresh fuel meat diameter / thickness $(\mathrm{cm})$} & 0.4174 & 0.3447 & 0.180 & 0.1845 \\
\hline \multicolumn{2}{|c|}{ Initial sodium gap thickness (microns) } & 323 & 266 & 300 & 307 \\
\hline \multicolumn{2}{|c|}{ Irradiated fuel meat diameter / thickness $(\mathrm{cm})^{\mathrm{a}}$} & 0.482 & 0.398 & 0.240 & 0.246 \\
\hline \multicolumn{2}{|l|}{ Wire wrap diameter $(\mathrm{cm})$} & 0.098 & 0.088 & - & - \\
\hline \multicolumn{2}{|l|}{ Pin pitch-to-diameter ratio } & 1.175 & 1.192 & - & - \\
\hline \multicolumn{2}{|c|}{ Coolant channel thickness between plates $(\mathrm{cm})$} & - & - & 0.173 & 0.157 \\
\hline \multicolumn{2}{|l|}{ Hydraulic diameter $(\mathrm{cm})$} & 0.253 & 0.214 & 0.308 & 0.289 \\
\hline \multicolumn{2}{|c|}{ Flow cross-sectional area $\left(\mathrm{cm}^{2}\right)$} & 37.9 & 38.6 & 35.6 & 31.5 \\
\hline \multicolumn{2}{|c|}{ Assembly surface-to-volume ratio $\left(\mathrm{cm}^{-1}\right)$} & 3.8 & 4.6 & 3.3 & 3.5 \\
\hline \multirow{4}{*}{$\begin{array}{c}\text { Fresh Fuel Volume } \\
\text { Fractions Averaged } \\
\text { Over Hexagonal Lattice }\end{array}$} & Sodium & $35.3 \%$ & $35.9 \%$ & $33.5 \%$ & $39.2 \%{ }^{\mathrm{d}}$ \\
\hline & Fuel & $29.7 \%$ & $29.7 \%$ & $29.7 \%$ & $29.7 \%$ \\
\hline & Fuel-Cladding Gap & $9.9 \%$ & $9.9 \%$ & $9.9 \%$ & $9.9 \%$ \\
\hline & Structure & $25.1 \%$ & $24.5 \%$ & $26.9 \%$ & $21.1 \%$ \\
\hline \multicolumn{2}{|c|}{ U-Pu mass (kg per cm of fuel assembly) } & 0.526 & 0.526 & 0.526 & 0.526 \\
\hline
\end{tabular}

${ }^{\mathrm{a}}$ Fuel meat diameter/thickness for burnup $>1 \%$. Assume contact with cladding. $\|^{\mathrm{b}}$ Same cladding thickness as EBR-II Mark-II fuel. $\|{ }^{\mathrm{c}}$ Plates average radii $(\mathrm{cm})$ are, $0.491,0.973,1.455,1.936,2.418,2.900,3.382,3.864,4.345,4.827$, and 5.309. $\|^{\mathrm{d}}$ Assume that the space between the cylindrical fuel assemblies is filled with sodium.

1 The temperature difference between the center and the periphery of fuel rods and plates are expressed as $\Delta T_{\text {fuel-rod }}=q_{\text {vol }} X$ $\left(r^{2} \div 4 k\right)$ and $\Delta T_{\text {fuel-plate }}=q_{v o l} \times\left(a^{2} \div 2 k\right)$ where $q_{v o l}$ is the power density in the fuel, $r$ is the fuel rod meat radius, $a$ is the fuel plate meat half-thickness and $k$ is the fuel thermal conductivity. The $r^{2} \div 4$ values corresponding to B271 and B397 are $1.45 \times 10^{-2} \mathrm{~cm}^{2}$ and $9.90 \times 10^{-3} \mathrm{~cm}^{2}$, respectively, whereas the $\mathrm{a}^{2} \div 2$ value corresponding to the plates is $7.38 \times 10^{-3} \mathrm{~cm}^{2}$. Hence, for the same fuel power density and thermal conductivity $\Delta \mathrm{T}_{\text {fuel-plate }}$ is $25 \%$ to $50 \%$ smaller than $\Delta \mathrm{T}_{\text {fuel-rod. }}$ 


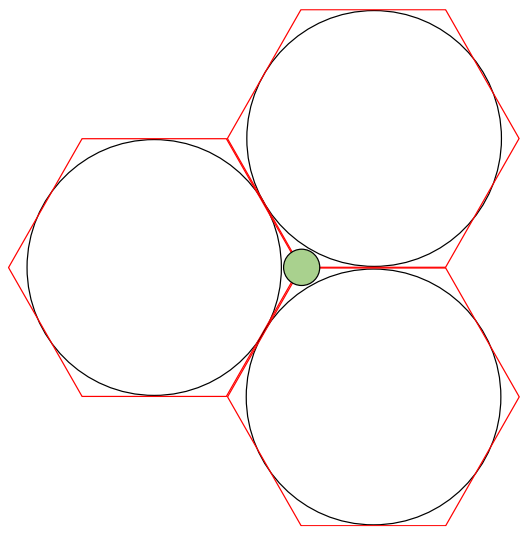

Figure 2.

Illustration of cylindrical fuel assemblies located on a grid plate designed for hexagonal fuel assemblies. The cylinders cover $90.690 \%$ of the area covered by the
hexagons.

The space left between the fuel assembly could in principle accommodate up to 1.85 -cm-diameter test locations (in green on the figure).

Typical sodium velocities in fuel pin bundles are 5 to $7 \mathrm{~m} / \mathrm{s}$. However, [Waltar, 2012] indicates that maximum velocities can reach values exceeding $10 \mathrm{~m} / \mathrm{s}$ such as in the Russian BOR-60 reactor $(11 \mathrm{~m} / \mathrm{s})$ or in the French Phénix reactor $(12 \mathrm{~m} / \mathrm{s})$. Though more detailed analyses are necessary to determine the maximum sodium velocity acceptable for specific configurations, the present study assumes, as a first approximation, that this velocity is the same as in Phénix (i.e., $12 \mathrm{~m} / \mathrm{s}$ ) for the 271-pin and 397-pin configurations considered in the present study. It is noteworthy that the diameter of the pins used in Phénix was $6.6 \mathrm{~mm}$, whereas it is $5.6 \mathrm{~mm}$ and $4.6 \mathrm{~mm}$ in the 271pin and 397-pin configurations, respectively. Therefore, the $12 \mathrm{~m} / \mathrm{s}$ may be optimistic for these two configurations. A discussion on the maximum acceptable coolant velocities in plate assemblies is presented in Section 4.

If the plates are sealed, have the same plenum-to-fuel height ratio as the reference pins (i.e., 1.0), and the plenum is located at the outlet where the peak sodium temperature is $550^{\circ} \mathrm{C}$, then, the maximum nominal plate internal pressure would also be about $5 \mathrm{MPa}$ whereas the external coolant pressure would be no more than a few tenths of an MPa. Preliminary analyses indicate that seven spacers located in each coolant channel may be sufficient to ensure that the flat plates can accommodate this pressure without excessive deformation (see Appendix B). If necessary, additional measures could also be implemented to reduce the plates internal pressure. $\underline{\mathbf{2}}$

Finally, damage (displacements per atom) to the cladding and test articles are estimated using, as a first approximation, a fast-fluence-to-dpa conversion factor of $2 \times \mathbf{1 0}^{\mathbf{2 1}} \mathbf{n} / \mathbf{c m}^{2}(>\mathbf{0 . 1} \mathbf{M e V})$ per dpa (see [Lemaignan, 2010] and [Puthiyavinayagam, 2009]). Similar conversion factors can be inferred from the results of detailed analyses presented, for example, in [Huang, 1992], [Aoyama, 2004], and [Eliseev, 2016].

$\underline{\mathbf{2}}$ For example, the plenum length could be increased at the cost of an increased pressure drop, or vented plates could be used that release fission gas directly to the primary coolant system. Sealed fuel elements have been classically used but vented fuel elements have also been used. For example, the British Dounreay (sodium-cooled) Fast Reactor (DFR) used a vented metallic fuel (U-xMo) design [Matthews, 1964] [Amorosi, 1966]. Several gas-cooled reactors also used, or still use, vented fuel elements: Peach Bottom Unit 1 in the US and several AGR plants in the UK [Klein, 2015]. Advanced reactor vendors such as General Atomics and TerraPower are also planning on using vented fuels [Klein, 2015]. Numerous patents have been filed on this topic (e.g., [US3996100A], [US4163689A], [US8929505B2]).

Another approach to reduce the internal plate pressure while adopting a sealed plate design is to locate the fission gas plenum at the core inlet where temperatures are lower. An upward sodium flow means that the fission gas plenum should be located below the fuel in order to be at the inlet —as in, for example, Phénix, Superphénix, and BN-350 — whereas, for a downward flow, it should be located on top of the fuel in order to be at the inlet. Except for DFR which had a downward flow [Graham, 1971], all sodium-cooled reactors have/had an upward flow. On the other hand, some high-performance (water-cooled) material test reactors have a downward flow (e.g., ATR and HFIR). Assuming a sodium inlet temperature of $200^{\circ} \mathrm{C}$ (see discussion about sodium inlet/outlet temperatures in Section 3), the peak plenum internal pressure would be about $2.9 \mathrm{MPa}$ compared to $5 \mathrm{MPa}$ if it were located at the outlet where the peak sodium temperature is $550^{\circ} \mathrm{C}$. Furthermore, since the coolant pressure at the inlet is typically about 1 to $1.5 \mathrm{MPa}$, the net peak plenum pressure would be about 1.4 to $1.9 \mathrm{MPa}$.

These potential approaches to reduce the plates internal pressure all have consequences on systems, normal operation, and upset conditions that should be carefully weighted with the intended benefit which is to increase the peak fast flux. More detailed analyses are necessary to quantify the pros and cons of each approach. 


\section{SODIUM INLET/OUTLET TEMPERATURES}

Most sodium-cooled fast reactors have operated, and still operate, with core-average inlet and outlet sodium temperatures of about $350-400^{\circ} \mathrm{C}$ and $500-550^{\circ} \mathrm{C}$, respectively [Waltar, 2012]. Notable exceptions are DFR in the UK, Fermi-1 in the US and BN-350 in Russia, which operated with inlet/outlet temperatures of $230 / 350^{\circ} \mathrm{C}, 288 / 427^{\circ} \mathrm{C}$, and $280 / 430^{\circ} \mathrm{C}$, respectively [Waltar, 2012]. The incentive to reach high outlet temperatures was to demonstrate that sodium-cooled reactors could reach high thermal efficiencies. With several decades of operational experience, this aspect of sodium-cooled reactors has been successfully demonstrated and is now well understood.

Therefore, a modern fast test reactor whose objectives are to reach a peak fast neutron flux that is as high as possible and to serve a diverse set of users (not only sodium-cooled reactor developers) could in principle operate with lower inlet and outlet sodium temperatures if it proved beneficial to increase the neutron flux. More prototypic environments could be obtained inside ad hoc irradiation testing vehicles that are independent from the reactor primary coolant [Sienicki, 2016]. ${ }^{-}$The core-average temperature difference between inlet and outlet, which is typically about $150^{\circ} \mathrm{C}$, could also be increased if it proved beneficial to increase the neutron flux.

In order to quantify the impact of the sodium inlet/outlet temperature on the achievable peak fast flux, the following sections present results obtained for two sets of operating conditions: one corresponding to typical operating temperatures and another corresponding to a reduced average operating temperature and higher outlet/inlet temperature difference. For the typical operating temperatures, the core inlet temperature is $350^{\circ} \mathrm{C}$ and the core-average outlet temperature is $500^{\circ} \mathrm{C}$, corresponding to a core-average $\Delta \mathrm{T}$ of $150^{\circ} \mathrm{C}$. The average sodium temperature at the outlet of the peak assembly is assumed to be $525^{\circ} \mathrm{C}$ whereas the sodium temperature at the outlet of the hottest channel within the peak assembly is assumed to be $550^{\circ} \mathrm{C}$. The reduced average operating temperature assumes an inlet temperature of $200^{\circ} \mathrm{C}$, a core-average outlet temperature of $400^{\circ} \mathrm{C}$, a core-average $\Delta \mathrm{T}$ of $200^{\circ} \mathrm{C}$, an outlet temperature of $425^{\circ} \mathrm{C}$ for the peak assembly, and an outlet temperature of $450^{\circ} \mathrm{C}$ for the hottest channel..$^{4}$

\section{CRITICAL COOLANT VELOCITY FOR FLAT PLATES}

It has been shown that above a certain flow velocity (the critical velocity) plates become unstable and large deflections can occur. These plate deflections can cause a local overheating of the fuel plates and possibly a complete blockage of the coolant flow. An expression for the critical velocity, $v_{c}$, can be obtained for arrays of flat parallel plates by assuming that the fuel meat has no structural strength but that it transmits the effects of shear and bending between the two cladding plates. Fuel plate manufacturing should ensure that this assumption is verified.

$$
\mathrm{v}_{\mathrm{c}}=\left[15 \times \mathrm{E}_{\mathrm{c}} \times \mathrm{t}_{\mathrm{Na}} \times\left(\mathrm{t}_{\mathrm{p}}{ }^{3}-\mathrm{t}_{\mathrm{f}}{ }^{3}\right)\right]^{1 / 2} \div\left[\rho_{\mathrm{Na}} \times \mathrm{w}_{\mathrm{p}}{ }^{4} \times\left(1-\mathrm{v}_{\mathrm{c}}{ }^{2}\right)\right]^{1 / 2},[\text { IAEA-TECDOC-233] }
$$

where $\mathrm{E}_{\mathrm{c}}$ is the cladding Young's elastic modulus $\left(165 \mathrm{GPa}\right.$ for steel at $\left.500^{\circ} \mathrm{C}\right), \mathrm{t}_{\mathrm{Na}}$ is the sodium coolant channel thickness $(1.73 \mathrm{~mm}), \mathrm{t}_{\mathrm{p}}$ is the plate thickness $(3.18 \mathrm{~mm}), \mathrm{t}_{\mathrm{f}}$ is the fuel thickness $(2.40 \mathrm{~mm}), \mathrm{w}_{\mathrm{p}}$ is the plate width $(62.35 \mathrm{~mm}), \rho_{\mathrm{Na}}$ is the sodium density $\left(850 \mathrm{~kg} / \mathrm{m}^{3}\right)$ and $v_{\mathrm{c}}$ is the cladding Poisson ratio $(0.3$ for steel).

Using these values, $v_{c}$ is equal to $82 \mathrm{~m} / \mathrm{s}$. A typical design criteria is that coolant velocity should not exceed $2 / 3$ of the critical velocity [IAEA-TECDOC-233]. Therefore, with respect to critical velocity, sodium velocity between the $\mathrm{J} 11$ fuel plates may be as high as $55 \mathrm{~m} / \mathrm{s}$. Critical velocities for curved plates, such as K11, are even higher than for flat plates. As will be shown in the next sections, sodium velocities never come close to this value.

\footnotetext{
$\underline{3}$ The same approach allows, for example, the Advanced Test Reactor (ATR) to perform irradiations under prototypic PWR conditions (water pressure and temperature of $15 \mathrm{MPa}$ and $320^{\circ} \mathrm{C}$, respectively) regardless of the fact that its primary coolant only operates at about $50-70^{\circ} \mathrm{C}$ and $2.5 \mathrm{MPa}$ [Grover, 2007], [Carmack, 2015].

4 Because structural materials in the driver fuel assemblies are not expected to accumulate more than 100 dpa over their lifetime (see Section 5), the typical operating temperatures could accommodate core structural materials made up of austenitic, ferritic, or ferritic-martensitic steels [Huang, 1992]. On the other hand, the reduced average operating temperature may not be appropriate for ferritic or ferritic-martensitic steels because of the increased ductile-brittle transition temperature (DBTT) experienced by these alloys when subjected to low-temperature irradiation. Austenitic steels are not susceptible to increased DBTT and may be used at the lower temperatures corresponding to the reduced average operating temperature.
} 


\section{CORE PERFORMANCE PRELIMINARY EVALUATION}

\subsection{Fuel and Cladding Maximum Allowable Nominal Temperature}

Independent of the reactor design, it is generally required that no incipient fuel melting should occur during normal operation and anticipated operational occurrences (AOOs), such as overpower conditions - even when 3- $\sigma$ uncertainties are considered. With typical sodium inlet/outlet temperatures of $350 / 550^{\circ} \mathrm{C}$ in the hottest core channel and a representative peak pin axial power distribution with a maximum value of $450 \mathrm{~W} / \mathrm{cm}$ (see Figure 3 , left), it can be shown that the nominal (i.e., w/o uncertainties) U-20Pu- $10 \mathrm{Zr}$ peak centerline temperature reaches about $840^{\circ} \mathrm{C}$ (see Figure 3, right). If sodium inlet/outlet temperatures in the hottest channel are $200 / 450^{\circ} \mathrm{C}$, the same fuel temperature is obtained for a peak linear power of $600 \mathrm{~W} / \mathrm{cm}$.
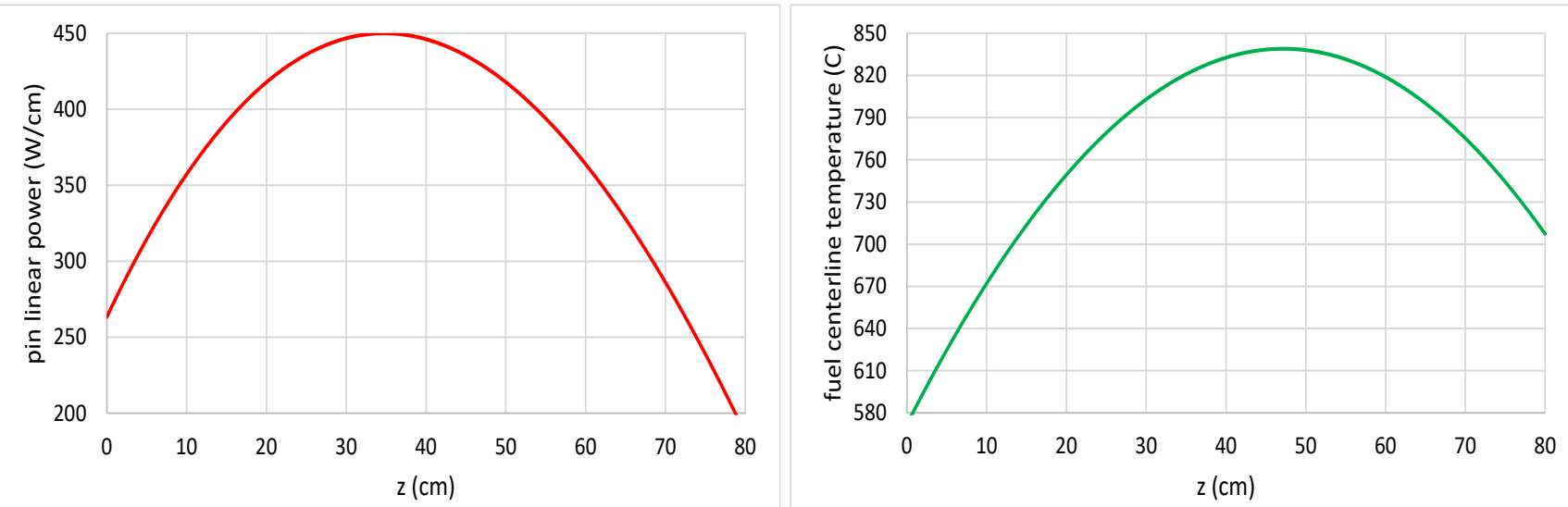

Figure 3. Peak pin linear power axial distribution (left) and fuel centerline temperature (right) for sodium inlet $/$ outlet temperatures $=350 / 550^{\circ} \mathrm{C}$ and $\mathrm{U}-20 \mathrm{Pu}-10 \mathrm{Zr}$ thermal conductivity $=0.11 \mathrm{~W} / \mathrm{cm}-\mathrm{K}$ (estimated minimum value at 1-2\% burnup based on correlations presented in [Billone, 1986]; more detailed calculations necessary).

This leaves a minimum nominal margin of $280^{\circ} \mathrm{C}$ with respect to incipient fuel centerline melting (nominal U$20 \mathrm{Pu}-10 \mathrm{Zr}$ solidus temperature $=1120^{\circ} \mathrm{C}$ ) and is typically considered sufficient to accommodate uncertainties and AOOs. Hence, in the following discussion, it is assumed that the nominal (i.e., w/o uncertainties) peak fuel temperature should not exceed $840^{\circ} \mathrm{C}$. The same maximum allowable peak fuel temperature $\left(840^{\circ} \mathrm{C}\right)$ is also assumed for plates.

Furthermore, to ensure that the cladding mechanical strength remains appropriate and also to ensure sufficient margin with respect to the U-Fe eutectic formation, it is typically required that the 3- $\sigma$ peak inside cladding temperature during normal operation does not exceed $650^{\circ} \mathrm{C}$. With peak sodium outlet temperatures of $450^{\circ} \mathrm{C}$ and $550^{\circ} \mathrm{C}$, nominal (i.e., w/o uncertainties) peak inside cladding temperatures are about $480^{\circ} \mathrm{C}$ and $570^{\circ} \mathrm{C}$, respectively. This leaves a minimum margin of $80^{\circ} \mathrm{C}$ which is considered adequate to accommodate uncertainties.

\subsection{Medium-Grade Fuel}

Assuming a U-20Pu-10Zr fuel using 72\%-fissile reactor-grade plutonium (238 to 242 isotope composition: 0/69/26/3/2) together with 5\% enriched uranium, the results presented in INL/EXT-20-57186 indicate that a 300 MW core containing 66 B271 fuel assemblies (see Figure 4) would meet fuel burnup objectives (10\% peak burnup) with a fuel residence time of 530 equivalent full power days (EFPD). This configuration is characterized by an average power density of $455 \mathrm{~W} / \mathrm{cm}^{3}$, a peak assembly power of $6.2 \mathrm{MW}$ and a peak fast flux $(>0.1 \mathrm{MeV})$ of $4.4 \times 10^{15} \mathrm{n} / \mathrm{cm}^{2}$-s. Corresponding peak cladding fast fluence and damage are $2.0 \times 10^{23} \mathrm{n} / \mathrm{cm}^{2}$ and $100 \mathrm{dpa}$, respectively. Assuming 300 EFPD of operation per calendar year, a test article could accumulate up to $57 \mathrm{dpa} / \mathrm{year}$. Since all fuel assemblies contain the same amount of fuel, as a first approximation, it is reasonable to assume that the number of fuel assemblies necessary will be the same independent of geometry. The same is also likely true for the peak fuel assembly power and the peak fast flux. As mentioned in Section 3, results presented in Table 2 include two sets of core-average inlet/outlet sodium temperatures $\left(350 / 500^{\circ} \mathrm{C}\right.$ and $\left.200 / 400^{\circ} \mathrm{C}\right)$. All configurations 
have significant margins (between $75^{\circ} \mathrm{C}$ and $315^{\circ} \mathrm{C}$ ) with respect to the assumed nominal fuel temperature limit of $840^{\circ} \mathrm{C}$.

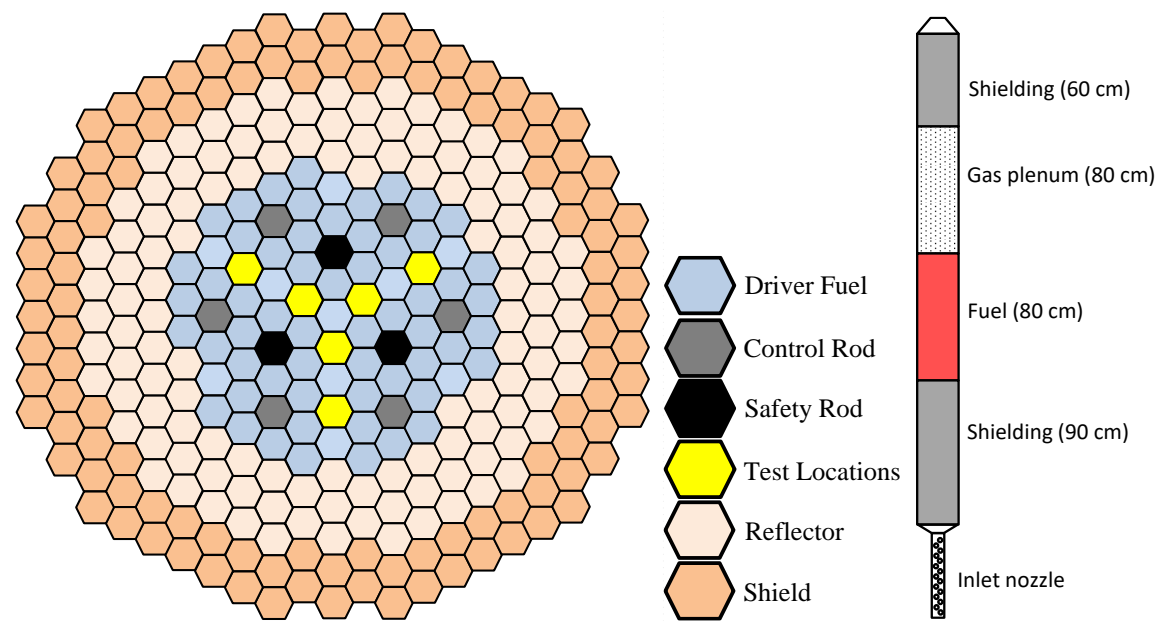

Figure 4.

Example of a 300-MW medium-grade-fuel core configuration - 66 driver fuel assemblies - Active core height $=80 \mathrm{~cm}$.

Peak fuel temperatures are $100-110^{\circ} \mathrm{C}$ lower with the reduced inlet/outlet temperatures than with the typical ones. Furthermore, for the same inlet/outlet sodium temperatures, the use of plates instead of pins leads to lower peak fuel temperatures. On the other hand, the use of plates does not impact peak cladding temperatures which mostly depends on the sodium temperatures at the outlet of the hot channel.

Table 2. Peak assembly thermal hydraulics characteristics for 66 fuel-assembly 300-MW core configurations using pins or plates. Results are presented for two sets of inlet/outlet sodium temperatures. Medium-grade fuel.

\begin{tabular}{|c|c|c|c|c|}
\hline Identifier & B271 & B397 & $\mathrm{J} 11$ & K11 \\
\hline Geometry & $\begin{array}{c}\text { Rods/Hex } \\
\text { Fig.1a }\end{array}$ & $\begin{array}{c}\text { Rods/Hex } \\
-\end{array}$ & $\begin{array}{c}\text { Plates/Hex } \\
\text { Fig.1b }\end{array}$ & $\begin{array}{c}\text { Plates/Cyl } \\
\text { Fig.1c }\end{array}$ \\
\hline Core power (MW) & 300 & 300 & 300 & 300 \\
\hline Number of fuel assemblies (FA) & 66 & 66 & 66 & 66 \\
\hline Core UPu inventory (metric ton) & 2.8 & 2.8 & 2.8 & 2.8 \\
\hline Peak ${ }^{\text {a }}$ FA power $(\mathrm{MW})$ & 6.2 & 6.2 & 6.2 & 6.2 \\
\hline Fuel active height $(\mathrm{cm}) /$ plenum height $(\mathrm{cm})$ & $80 / 80$ & $80 / 80$ & $80 / 80$ & $80 / 80$ \\
\hline Average inlet/outlet sodium $\mathrm{T}$ in peak FA $\left({ }^{\circ} \mathrm{C}\right)$ & \multicolumn{4}{|c|}{$350 / 525:: 200 / 425$} \\
\hline Na velocity in fuel bundle $(\mathrm{m} / \mathrm{s})$ & $8.5:: 6.4$ & $8.3:: 6.3$ & $9.0:: 6.8$ & $10.2:: 7.6$ \\
\hline Peak ${ }^{a}$ fuel power density $\left(\mathrm{W} / \mathrm{cm}^{3}\right)$ & 1965 & 1965 & 1965 & 1965 \\
\hline Peak ${ }^{\mathrm{a}}$ linear power $(\mathrm{W} / \mathrm{cm})$ & 360 & 245 & - & - \\
\hline Peak ${ }^{\mathrm{a}} \mathrm{U}-20 \mathrm{Pu}-10 \mathrm{Zr} \Delta \mathrm{T}^{\mathrm{b}}\left({ }^{\circ} \mathrm{C}\right)$ & 260 & 180 & 130 & 135 \\
\hline Peak ${ }^{\mathrm{a}} \mathrm{U}-20 \mathrm{Pu}-10 \mathrm{Zr}$ centerline $\mathrm{T}\left({ }^{\circ} \mathrm{C}\right)$ & $765:: 650$ & $680:: 570$ & $635:: 525$ & $640:: 530$ \\
\hline Peak ${ }^{\mathrm{a}}$ cladding $\mathrm{T}\left({ }^{\circ} \mathrm{C}\right)$ & $570:: 470$ & $570:: 470$ & $570:: 470$ & $570:: 470$ \\
\hline Peak ${ }^{\mathrm{a}}$ fast flux $>0.1 \mathrm{MeV}\left(\mathrm{n} / \mathrm{cm}^{2}-\mathrm{s}\right)$ & $4.4 \times 10^{15}$ & $4.4 \times 10^{15}$ & $4.4 \times 10^{15}$ & $4.4 \times 10^{15}$ \\
\hline$\Delta \mathrm{p}=\left\{\mathrm{f} \times \mathrm{L} / \mathrm{D}_{\mathrm{h}}\right\} \times\left\{\rho \mathrm{v}^{2} / 2\right\}(\mathrm{MPa})^{\mathrm{c}}$ & $0.39:: 0.25$ & $0.46:: 0.29$ & $0.34:: 0.22$ & $0.45:: 0.28$ \\
\hline
\end{tabular}

${ }^{\mathrm{a}}$ Nominal value, i.e., w/o uncertainties. $\|{ }^{\mathrm{b}} \mathrm{U}-20 \mathrm{Pu}-10 \mathrm{Zr}$ thermal conductivity $=0.11 \mathrm{~W} / \mathrm{cm}-\mathrm{K}$ (estimated minimum value at 1 $2 \%$ burnup based on correlations presented in [Billone, 1986] - more detailed calculations necessary). $\|{ }^{\mathrm{c}}$ Calculated with ChengTodreas correlation for wire-wrap fuel rods and with Colebrook's correlation for plates (roughness parameter $=10^{-4}$ ).

Hence, with respect to increasing the peak fast flux while maintaining sufficient operational margins, there does not seem to be any strong incentives to favor one configuration over another. However, extra fuel thermal margins may be used to increase the plutonium content in the fuel and reduce the level of uranium enrichment needed (U$\mathrm{xPu}-10 \mathrm{Zr}$ thermal conductivity and solidus temperature decrease as $\mathrm{x}$ increases, hence, necessitating additional thermal margins). For example, increasing the plutonium content from the reference $20 \%$ up to about $23 \%$ would allow for lowering uranium enrichment from 5\% down to natural uranium, hence, cutting down on fuel cost. 


\subsection{High-Grade Fuel}

Assuming a U-20Pu-10Zr fuel using 94\%-fissile weapons-grade plutonium (238 to 242 isotope composition: 0/94/6/0/0) together with $10 \%$ enriched uranium, the results presented in INL/EXT-20-57186 indicate that a 215 MW core made up of $46 \mathrm{~B} 271$ fuel assemblies (active height $=60 \mathrm{~cm}$ ) would meet fuel burnup objectives $(10 \%$ peak burnup) with a fuel residence time of 420 EFPD. Average power density is $625 \mathrm{~W} / \mathrm{cm}^{3}$. Peak assembly power is $5.9 \mathrm{MW}$ corresponding to a peak pin linear power of $450 \mathrm{~W} / \mathrm{cm}$. Peak fast flux $(>0.1 \mathrm{MeV})$ is $4.4 \times 10^{15} \mathrm{n} / \mathrm{cm}^{2}-$ s. Corresponding peak cladding fast fluence and damage are $1.6 \times 10^{23} \mathrm{n} / \mathrm{cm}^{2}$ and $80 \mathrm{dpa}$, respectively. Assuming 300 EFPD of operation per calendar year, a test article could accumulate up to $57 \mathrm{dpa} /$ year. The core power for this 46-B271 fuel-assembly configuration is limited by the fuel temperature $\left(840^{\circ} \mathrm{C}\right)$ when the core-average inlet/outlet temperatures are $350^{\circ} \mathrm{C} / 500^{\circ} \mathrm{C}$. Lowering inlet/outlet temperatures generates additional margins with respect to fuel and cladding temperature limits.

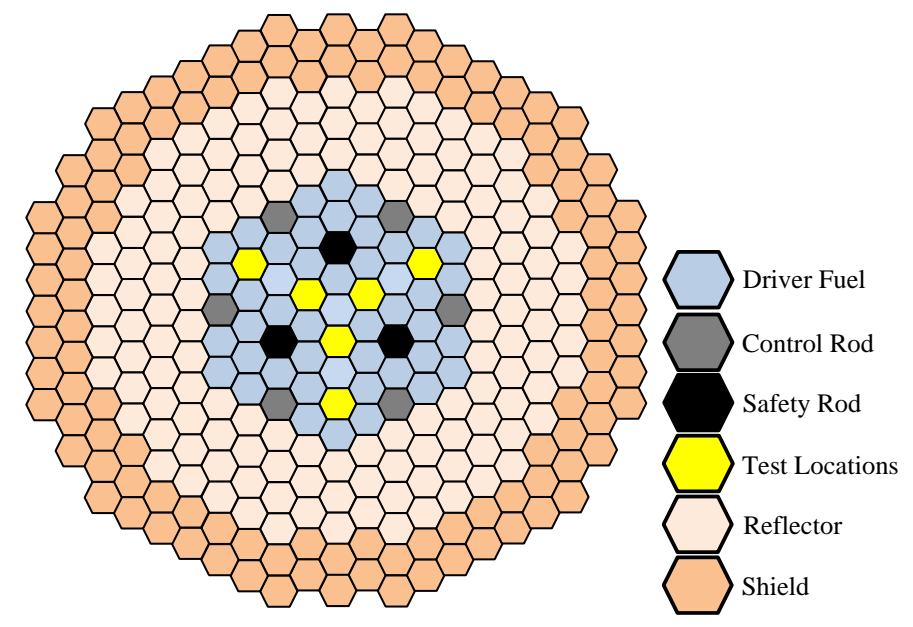

Figure 5 .

Example of a 215-MW high-grade-fuel core configuration - 46 driver fuel assemblies Active core height $=60 \mathrm{~cm}$.

Core power may be increased up to $300 \mathrm{MW}$ with appropriate fuel assembly design and operating temperatures.

Table 3. Peak assembly thermal hydraulics characteristics for 46 fuel-assembly 215 -MW core configurations using pins or plates. Results are presented for two sets of inlet/outlet sodium temperatures. High-grade fuel.

\begin{tabular}{|c|c|c|c|c|}
\hline Identifier & B271 & B397 & $\mathrm{J} 11$ & K11 \\
\hline Geometry & $\begin{array}{l}\text { Rods/Hex } \\
\text { Fig.1a }\end{array}$ & $\begin{array}{c}\text { Rods/Hex } \\
-\end{array}$ & $\begin{array}{l}\text { Plates/Hex } \\
\text { Fig. } 1 \mathrm{~b}\end{array}$ & $\begin{array}{c}\text { Plates/Cyl } \\
\text { Fig.1c }\end{array}$ \\
\hline Core power (MW) & 215 & 215 & 215 & 215 \\
\hline Number of fuel assemblies (FA) & 46 & 46 & 46 & 46 \\
\hline Core UPu inventory (metric ton) & 1.4 & 1.4 & 1.4 & 1.4 \\
\hline Peak ${ }^{a}$ FA power $(M W)$ & 5.9 & 5.9 & 5.9 & 5.9 \\
\hline Fuel active height $(\mathrm{cm}) /$ plenum height $(\mathrm{cm})$ & $60 / 60$ & $60 / 60$ & $60 / 60$ & $60 / 60$ \\
\hline Average inlet/outlet sodium $\mathrm{T}$ in peak FA $\left({ }^{\circ} \mathrm{C}\right)$ & \multicolumn{4}{|c|}{$350 / 525:: 200 / 425$} \\
\hline $\mathrm{Na}$ velocity in fuel bundle $(\mathrm{m} / \mathrm{s})$ & $8.0:: 6.0$ & $7.9:: 5.9$ & $8.6:: 6.5$ & $9.6:: 7.2$ \\
\hline Peak ${ }^{a}$ fuel power density $\left(\mathrm{W} / \mathrm{cm}^{3}\right)$ & 2465 & 2465 & 2465 & 2465 \\
\hline Peak ${ }^{\mathrm{a}}$ linear power $(\mathrm{W} / \mathrm{cm})$ & 450 & 310 & - & - \\
\hline Peak ${ }^{\mathrm{a}} \mathrm{U}-20 \mathrm{Pu}-10 \mathrm{Zr}$ fuel $\Delta \mathrm{T}^{\mathrm{b}}\left({ }^{\circ} \mathrm{C}\right)$ & 325 & 225 & 165 & 170 \\
\hline Peak ${ }^{\text {a }} \mathrm{U}-20 \mathrm{Pu}-10 \mathrm{Zr}$ fuel temp. $\left({ }^{\circ} \mathrm{C}\right)$ & $840:: 720$ & $740:: 615$ & $665:: 555$ & $670:: 560$ \\
\hline Peak ${ }^{\mathrm{a}}$ cladding $\mathrm{T}\left({ }^{\circ} \mathrm{C}\right)$ & $570:: 470$ & $570:: 470$ & $570:: 470$ & $570:: 470$ \\
\hline Peak ${ }^{\mathrm{a}}$ fast flux $>0.1 \mathrm{MeV}\left(\mathrm{n} / \mathrm{cm}^{2}-\mathrm{s}\right)$ & $4.4 \times 10^{15}$ & $4.4 \times 10^{15}$ & $4.4 \times 10^{15}$ & $4.4 \times 10^{15}$ \\
\hline$\Delta \mathrm{p}=\left\{\mathrm{f} \times \mathrm{L} / \mathrm{D}_{\mathrm{h}}\right\} \times\left\{\rho \mathrm{v}^{2} / 2\right\}(\mathrm{MPa})^{\mathrm{c}}$ & $0.26:: 0.17$ & $0.31:: 0.20$ & $0.23:: 0.15$ & $0.31:: 0.20$ \\
\hline
\end{tabular}

${ }^{a}$ Nominal value, i.e., w/o uncertainties. $\|^{\mathrm{b}} \mathrm{U}-20 \mathrm{Pu}-10 \mathrm{Zr}$ thermal conductivity $=0.11 \mathrm{~W} / \mathrm{cm}-\mathrm{K}$ (estimated minimum value at 1 $2 \%$ burnup based on correlations presented in [Billone, 1986] - more detailed calculations necessary). $\|{ }^{\mathrm{c}}$ Calculated with ChengTodreas correlation for wire-wrap fuel rods and with Colebrook's correlation for plates (roughness parameter $=10^{-4}$ ). 
For the same inlet/outlet temperature, increasing the number of fuel pins from the reference 271 to 397 reduces the peak fuel centerline temperature by about $100^{\circ} \mathrm{C}$. For the same inlet/outlet temperature, using the J11 or K11 fuel plate assemblies instead of the reference B271 assembly lowers the peak fuel centerline temperature by about $170^{\circ} \mathrm{C}$. The additional fuel thermal margins resulting from lowering inlet/outlet temperatures, from increasing the number of fuel pins, or from using fuel plates can in principle be used to increase the core power and, consequently, the peak fast flux.

If, with the $200 / 400^{\circ} \mathrm{C}$ core-average inlet/outlet temperatures, the core power of $46-\mathrm{B} 271$ fuel-assembly configuration were increased from $215 \mathrm{MW}$ to $300 \mathrm{MW}$, the peak fuel temperature would only slightly exceed the assumed limit $\left(865^{\circ} \mathrm{C}\right.$ instead of $\left.840^{\circ} \mathrm{C}\right)$. Average core power density increases from 625 to $870 \mathrm{~W} / \mathrm{cm}^{3}$. As a direct consequence of the increased power density, the peak fast flux reaches $6.1 \times 10^{15} \mathbf{n} / \mathbf{c m}^{2}$-s and fuel residence time is reduced to 300 EFPD. Corresponding peak cladding fast fluence and damage are $1.6 \times 10^{23} \mathrm{n} / \mathrm{cm}^{2}$ and 80 dpa, respectively. Assuming 300 EFPD of operation per calendar year, a test article could accumulate up to 80 dpa/year. Sodium velocity is $8.4 \mathrm{~m} / \mathrm{s}$. Using the B397 fuel assembly, the core power can in principle be increased from $215 \mathrm{MW}$ up to $300 \mathrm{MW}$ for both sets of inlet/outlet sodium temperatures. At this point the nominal peak pin linear power reaches $430 \mathrm{~W} / \mathrm{cm}$ and the nominal peak fuel temperature reaches $820^{\circ} \mathrm{C}$ or $755^{\circ} \mathrm{C}$ depending on the inlet/outlet temperatures. The peak fast flux also reaches $6.1 \times 10^{15} \mathrm{n} / \mathrm{cm}^{2}$-s. The sodium velocity corresponding to the $350 / 500^{\circ} \mathrm{C}$ and $200 / 400^{\circ} \mathrm{C}$ core-average inlet/outlet temperatures are $11.0 \mathrm{~m} / \mathrm{s}$ and $8.3 \mathrm{~m} / \mathrm{s}$, respectively.

With the J11 and K11 plate fuel assemblies the core power can also be increased up to $300 \mathrm{MW}$. At this point the nominal peak fuel temperature in the $\mathrm{J} 11$ fuel assemblies reaches $730^{\circ} \mathrm{C}$ or $615^{\circ} \mathrm{C}$ depending on the inlet/outlet temperatures. The nominal peak fuel temperature obtained in the $\mathrm{K} 11$ fuel assemblies are similar (i.e., $745^{\circ} \mathrm{C}$ and $630^{\circ} \mathrm{C}$, respectively). As a direct consequence of the increased power, the peak fast flux reaches the same value as the pin configurations, i.e., $6.1 \times 10^{15} \mathrm{n} / \mathrm{cm}^{2}$-s. Depending on the inlet/outlet temperatures, sodium velocities are $11.9 \mathrm{~m} / \mathrm{s}$ and $9.0 \mathrm{~m} / \mathrm{s}$ in the $\mathrm{J} 11$ peak assembly and $13.4 \mathrm{~m} / \mathrm{s}$ and $10.0 \mathrm{~m} / \mathrm{s}$ in the K11 peak assembly, respectively.

The large fuel thermal margins available with plates may be used to increase the $\mathrm{Pu}$ content and minimize the need for uranium enrichment. For example, increasing the plutonium content from the reference $20 \%$ up to about $24 \%$ would allow for lowering uranium enrichment from 10\% down to natural uranium.

Table 4. Peak assembly thermal hydraulics characteristics for 46 fuel-assembly 300-MW core configurations using pins or plates. High-grade fuel.

\begin{tabular}{|c|c|c|c|c|}
\hline Identifier & $\mathrm{B} 271$ & B397 & $\mathrm{J} 11$ & K11 \\
\hline Geometry & $\begin{array}{c}\text { Rods/Hex } \\
-\end{array}$ & $\begin{array}{c}\text { Rods/Hex } \\
-\end{array}$ & $\begin{array}{l}\text { Plates/Hex } \\
\text { Fig.1b }\end{array}$ & $\begin{array}{c}\text { Plates/Cyl } \\
\text { Fig.1c }\end{array}$ \\
\hline Core power (MW) & 300 & 300 & 300 & 300 \\
\hline Number of fuel assemblies (FA) & 46 & 46 & 46 & 46 \\
\hline Core UPu inventory (metric ton) & 1.4 & 1.4 & 1.4 & 1.4 \\
\hline Peak ${ }^{\mathrm{a}}$ FA power (MW) & 8.2 & 8.2 & 8.2 & 8.2 \\
\hline Fuel active height $(\mathrm{cm}) /$ plenum height $(\mathrm{cm})$ & $60 / 60$ & $60 / 60$ & $60 / 60$ & $60 / 60$ \\
\hline Average inlet/outlet sodium $\mathrm{T}$ in peak FA $\left({ }^{\circ} \mathrm{C}\right)$ & \multicolumn{4}{|c|}{$350 / 525:: 200 / 425$} \\
\hline Na velocity in fuel bundle $(\mathrm{m} / \mathrm{s})$ & $\mathrm{n} / \mathrm{a}:: 8.4$ & $11.0:: 8.3$ & $11.9:: 9.0$ & $13.4:: 10.0$ \\
\hline Peak ${ }^{a}$ fuel power density $\left(\mathrm{W} / \mathrm{cm}^{3}\right)$ & 3460 & 3460 & 3460 & 3460 \\
\hline Peak ${ }^{\mathrm{a}}$ linear power $(\mathrm{W} / \mathrm{cm})$ & 625 & 430 & - & - \\
\hline Peak ${ }^{\mathrm{a}} \mathrm{U}-20 \mathrm{Pu}-10 \mathrm{Zr}$ fuel $\Delta \mathrm{T}^{\mathrm{b}}\left({ }^{\circ} \mathrm{C}\right)$ & 455 & 310 & 225 & 240 \\
\hline Peak ${ }^{\text {a }} \mathrm{U}-20 \mathrm{Pu}-10 \mathrm{Zr}$ fuel temp. $\left({ }^{\circ} \mathrm{C}\right)$ & $\mathrm{n} / \mathrm{a}:: 865$ & $820:: 705$ & $730:: 615$ & $745:: 630$ \\
\hline Peak ${ }^{\mathrm{a}}$ cladding $\mathrm{T}\left({ }^{\circ} \mathrm{C}\right)$ & $\mathrm{n} / \mathrm{a}:: 480$ & $570:: 470$ & $570:: 470$ & $570:: 470$ \\
\hline Peak ${ }^{\mathrm{a}}$ fast flux $>0.1 \mathrm{MeV}\left(\mathrm{n} / \mathrm{cm}^{2}-\mathrm{s}\right)$ & $6.1 \times 10^{15}$ & $6.1 \times 10^{15}$ & $6.1 \times 10^{15}$ & $6.1 \times 10^{15}$ \\
\hline$\Delta \mathrm{p}=\left\{\mathrm{f} \times \mathrm{L} / \mathrm{D}_{\mathrm{h}}\right\} \times\left\{\rho \mathrm{v}^{2} / 2\right\}(\mathrm{MPa})^{\mathrm{c}}$ & $\mathrm{n} / \mathrm{a}:: 0.31$ & $0.57:: 0.36$ & $0.42:: 0.27$ & $0.57:: 0.36$ \\
\hline
\end{tabular}

${ }^{a}$ Nominal value, i.e., w/o uncertainties. $\|{ }^{\mathrm{b}} \mathrm{U}-20 \mathrm{Pu}-10 \mathrm{Zr}$ thermal conductivity $=0.11 \mathrm{~W} / \mathrm{cm}-\mathrm{K}$ (estimated minimum value at 1 $2 \%$ burnup based on correlations presented in [Billone, 1986] - more detailed calculations necessary). $\|{ }^{\mathrm{c}}$ Calculated with ChengTodreas correlation for wire-wrap fuel rods and with Colebrook's correlation for plates (roughness parameter $=10^{-4}$ ). 


\subsection{Super-High-Grade Fuel}

Assuming a U-20Pu-10Zr fuel using 94\%-fissile weapons-grade plutonium (238 to 242 isotope composition: 0/94/6/0/0) together with $20 \%$ enriched uranium, the results presented in INL/EXT-20-57186 indicate that a 145 MW core made up of $29 \mathrm{~B} 271$ fuel assemblies (active height $=60 \mathrm{~cm})$ would meet fuel burnup objectives $(10 \%$ peak burnup) with a fuel residence time of $420 \mathrm{EFPD}$. Average power density is $670 \mathrm{~W} / \mathrm{cm}^{3}$. Peak assembly power is $5.9 \mathrm{MW}$. Peak fast flux is $3.8 \times 10^{15} \mathrm{n} / \mathrm{cm}^{2}$-s. Corresponding peak cladding fast fluence and damage are $1.4 \times 10^{23}$ $\mathrm{n} / \mathrm{cm}^{2}$ and $69 \mathrm{dpa}$, respectively. Assuming 300 EFPD of operation per calendar year, a test article could accumulate up to $49 \mathrm{dpa}$ /year. The core power for this 29-B271 fuel-assembly configuration is limited by the fuel temperature $\left(840^{\circ} \mathrm{C}\right)$ when core-average inlet/outlet temperatures are $350 / 500^{\circ} \mathrm{C}$. Lowering inlet/outlet temperatures generate additional margins with respect to fuel and cladding temperature limits. For the same inlet/outlet temperature, increasing the number of fuel pins from the reference 271 to 397 lowers the peak fuel centerline temperature by about $100^{\circ} \mathrm{C}$. For the same inlet/outlet temperature, using the $\mathrm{J} 11$ or $\mathrm{K} 11$ fuel plate assemblies instead of the reference B271 assembly lowers the peak fuel centerline temperature by about $170^{\circ} \mathrm{C}$.

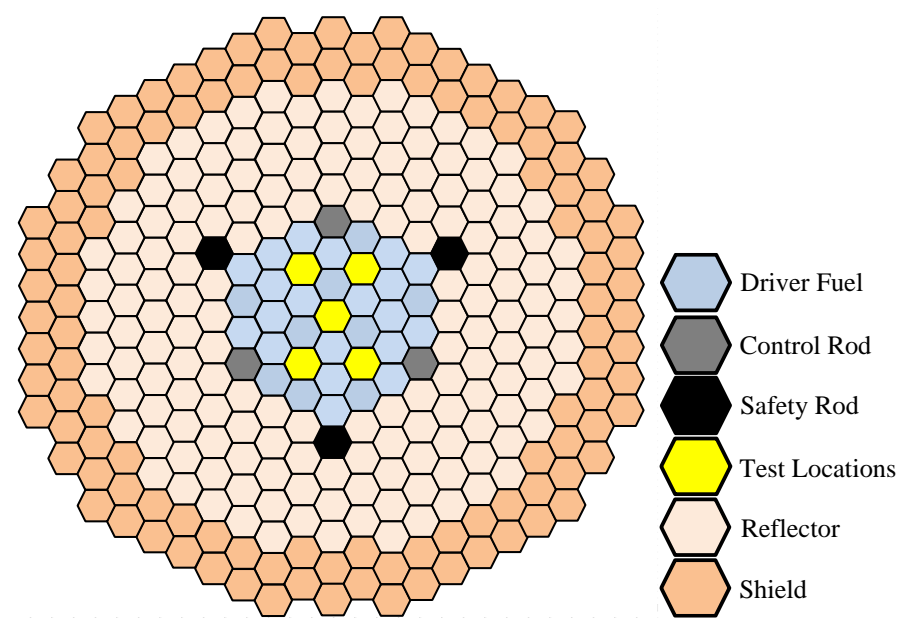

Figure 6.

Example of a 145-MW super-high-grade fuel core configuration - 29 driver fuel assemblies - Active core height $=60 \mathrm{~cm}$.

Core power may be increased up to $300 \mathrm{MW}$ with appropriate fuel assembly design and operating temperatures.

Table 5. Peak assembly thermal hydraulics characteristics for 29 fuel-assembly 145-MW core configurations using pins or plates. Super-high-grade fuel.

\begin{tabular}{|l|c|c|c|c|}
\hline Identifier & B271 & B397 & J11 & K11 \\
\hline Geometry & $\begin{array}{c}\text { Rods/Hex } \\
\text { Fig.1a }\end{array}$ & $\begin{array}{c}\text { Rods/Hex } \\
-\end{array}$ & $\begin{array}{c}\text { Plates/Hex } \\
\text { Fig.1b }\end{array}$ & $\begin{array}{c}\text { Plates/Cyl } \\
\text { Fig.1c }\end{array}$ \\
\hline Core power $(\mathrm{MW})$ & 145 & 145 & 145 & 145 \\
\hline Number of fuel assemblies (FA) & 29 & 29 & 29 & 29 \\
\hline Core UPu inventory (metric ton) & 0.92 & 0.92 & 0.92 & 0.92 \\
\hline Peak ${ }^{a}$ FA power $(\mathrm{MW})$ & 5.9 & 5.9 & 5.9 & 5.9 \\
\hline Fuel active height $(\mathrm{cm}) /$ plenum height $(\mathrm{cm})$ & $60 / 60$ & $60 / 60$ & $60 / 60$ & $60 / 60$ \\
\hline Average inlet/outlet sodium T in peak FA $\left({ }^{\circ} \mathrm{C}\right)$ & \multicolumn{4}{|c|}{} \\
\hline Na velocity in fuel bundle $(\mathrm{m} / \mathrm{s})$ & $8.0:: 6.0$ & $7.9:: 5.9$ & $8.6:: 6.5$ & $9.6:: 7.2$ \\
\hline Peak ${ }^{a}$ fuel power density $\left(\mathrm{W} / \mathrm{cm}^{3}\right)$ & 2465 & 2465 & 2465 & 2465 \\
\hline Peak ${ }^{a}$ linear power $(\mathrm{W} / \mathrm{cm})$ & 450 & 310 & - & - \\
\hline Peak ${ }^{a} \mathrm{U}-20 \mathrm{Pu}-10 \mathrm{Zr}$ fuel $\Delta \mathrm{T}{ }^{\mathrm{b}}\left({ }^{\circ} \mathrm{C}\right)$ & 325 & 225 & 165 & 170 \\
\hline Peak ${ }^{\mathrm{a}} \mathrm{U}-20 \mathrm{Pu}-10 \mathrm{Zr}$ fuel temp. $\left({ }^{\circ} \mathrm{C}\right)$ & $840:: 720$ & $740:: 615$ & $665:: 555$ & $670:: 560$ \\
\hline Peak ${ }^{a}$ cladding $\mathrm{T}\left({ }^{\circ} \mathrm{C}\right)$ & $570:: 470$ & $570:: 470$ & $570:: 470$ & $570:: 470$ \\
\hline Peak ${ }^{a}$ fast flux $>0.1 \mathrm{MeV}\left(\mathrm{n} / \mathrm{cm}^{2}\right.$-s) & $3.8 \times 10^{15}$ & $3.8 \times 10^{15}$ & $3.8 \times 10^{15}$ & $3.8 \times 10^{15}$ \\
\hline$\Delta \mathrm{p}=\left\{\mathrm{f} \times \mathrm{L} / \mathrm{D}_{\mathrm{h}}\right\} \times\left\{\rho v^{2} / 2\right\}(\mathrm{MPa})^{\mathrm{c}}$ & $0.26:: 0.17$ & $0.31:: 0.20$ & $0.23:: 0.15$ & $0.31:: 0.20$ \\
\hline
\end{tabular}

${ }^{\mathrm{a}}$ Nominal value, i.e., w/o uncertainties. $\|{ }^{\mathrm{b}} \mathrm{U}-20 \mathrm{Pu}-10 \mathrm{Zr}$ thermal conductivity $=0.11 \mathrm{~W} / \mathrm{cm}-\mathrm{K}$ estimated minimum value at 1 $2 \%$ burnup based on correlations presented in [Billone, 1986] - more detailed calculations necessary). $\|{ }^{\mathrm{c}}$ Calculated with ChengTodreas correlation for wire-wrap fuel rods and with Colebrook's correlation for plates (roughness parameter $=10^{-4}$ ). 
The additional fuel thermal margins resulting from lowering inlet/outlet temperatures, from increasing the number of fuel pins, or from using fuel plates can in principle be used to increase the core power (and peak fast flux). If, with the $200 / 400^{\circ} \mathrm{C}$ core-average inlet/outlet temperatures, the core power of 29-B397 fuel-assembly configuration were increased from $145 \mathrm{MW}$ to $300 \mathrm{MW}$, the peak fuel temperature would only slightly exceed the assumed limit $\left(875^{\circ} \mathrm{C}\right.$ instead of $\left.840^{\circ} \mathrm{C}\right)$. Average core power density increases from 670 to $1,385 \mathrm{~W} / \mathrm{cm}^{3}$. As a direct consequence of the increased power density, the peak fast flux reaches $7.9 \times 10^{15} \mathbf{n} / \mathbf{c m}^{2}$-s and fuel residence time is reduced to 205 EFPD. Corresponding peak cladding fast fluence and damage are $1.4 \times 10^{23} \mathrm{n} / \mathrm{cm}^{2}$ and $69 \mathrm{dpa}$, respectively. Assuming 300 EFPD of operation per calendar year, a test article could accumulate up to 100 dpa/year. Sodium velocity is $12.3 \mathrm{~m} / \mathrm{s}$. As mentioned in Section 2, peak sodium velocity in Phénix was also about $12 \mathrm{~m} / \mathrm{s}$; however, more detailed analyses are necessary to determine whether the B397 assembly could also accommodate this high velocity. With the J11 or K11 plate fuel assemblies the core power can also be increased to $300 \mathrm{MW}$ and the peak fast flux also reaches $7.9 \times 10^{15} \mathrm{n} / \mathrm{cm}^{2}$-s. Depending on the inlet/outlet temperatures, sodium velocities are $17.7 \mathrm{~m} / \mathrm{s}$ and $13.3 \mathrm{~m} / \mathrm{s}$ in the $\mathrm{J} 11$ peak assembly and $20.0 \mathrm{~m} / \mathrm{s}$ and $15.0 \mathrm{~m} / \mathrm{s}$ in the $\mathrm{K} 11$ peak assembly, respectively.

Table 6. Peak assembly thermal hydraulics characteristics for 29 fuel-assembly 300-MW core configurations using pins or plates. Results are presented for 2 sets of inlet/outlet sodium temperatures. Super-high-grade fuel.

\begin{tabular}{|c|c|c|c|}
\hline Identifier & B397 & $\mathrm{J} 11$ & K11 \\
\hline Geometry & $\begin{array}{c}\text { Rods/Hex } \\
-\end{array}$ & $\begin{array}{c}\text { Plates/Hex } \\
\text { Fig.1b }\end{array}$ & $\begin{array}{c}\text { Plates/Cyl } \\
\text { Fig.1c }\end{array}$ \\
\hline Core power (MW) & 300 & 300 & 300 \\
\hline Number of fuel assemblies (FA) & 29 & 29 & 29 \\
\hline Core UPu inventory (metric ton) & 0.92 & 0.92 & 0.92 \\
\hline Peak ${ }^{a}$ FA power $(M W)$ & 12.2 & 12.2 & 12.2 \\
\hline Fuel active height $(\mathrm{cm}) /$ plenum height $(\mathrm{cm})$ & $60 / 60$ & $60 / 60$ & $60 / 60$ \\
\hline Average inlet/outlet sodium $\mathrm{T}$ in peak FA $\left({ }^{\circ} \mathrm{C}\right)$ & \multicolumn{3}{|c|}{$350 / 525:: 200 / 425$} \\
\hline $\mathrm{Na}$ velocity in fuel bundle $(\mathrm{m} / \mathrm{s})$ & $\mathrm{n} / \mathrm{a}:: 12.3$ & $17.7:: 13.3$ & $20.0^{\mathrm{e}}:: 15.0$ \\
\hline Peak ${ }^{a}$ fuel power density $\left(\mathrm{W} / \mathrm{cm}^{3}\right)$ & 5145 & 5145 & 5145 \\
\hline Peak ${ }^{\mathrm{a}}$ linear power $(\mathrm{W} / \mathrm{cm})$ & 640 & - & - \\
\hline Peak ${ }^{\mathrm{a}} \mathrm{U}-20 \mathrm{Pu}-10 \mathrm{Zr}$ fuel $\Delta \mathrm{T}^{\mathrm{b}}\left({ }^{\circ} \mathrm{C}\right)$ & 465 & 335 & 355 \\
\hline Peak ${ }^{\text {a }} \mathrm{U}-20 \mathrm{Pu}-10 \mathrm{Zr}$ fuel temp. $\left({ }^{\circ} \mathrm{C}\right)$ & $\mathrm{n} / \mathrm{a}:: 875$ & $850:: 730$ & $870:: 750$ \\
\hline Peak ${ }^{\mathrm{a}}$ cladding $\mathrm{T}\left({ }^{\circ} \mathrm{C}\right)$ & $\mathrm{n} / \mathrm{a}:: 480$ & $570:: 480$ & $570:: 480$ \\
\hline Peak ${ }^{\mathrm{a}}$ fast flux $>0.1 \mathrm{MeV}\left(\mathrm{n} / \mathrm{cm}^{2}-\mathrm{s}\right)$ & $7.9 \times 10^{15}$ & $7.9 \times 10^{15}$ & $7.9 \times 10^{15}$ \\
\hline$\Delta \mathrm{p}=\left\{\mathrm{f} \times \mathrm{L} / \mathrm{D}_{\mathrm{h}}\right\} \times\left\{\rho \mathrm{v}^{2} / 2\right\}(\mathrm{MPa})^{\mathrm{c}}$ & $\mathrm{n} / \mathrm{a}:: 0.76$ & $0.87^{\mathrm{d}}:: 0.55$ & $1.17^{\mathrm{f}}:: 0.74$ \\
\hline
\end{tabular}

${ }^{\mathrm{a}}$ Nominal value, i.e., w/o uncertainties. $\|{ }^{\mathrm{b}} \mathrm{U}-20 \mathrm{Pu}-10 \mathrm{Zr}$ thermal conductivity $=0.11 \mathrm{~W} / \mathrm{cm}-\mathrm{K}$ (estimated minimum value at $1-2 \%$ burnup based on correlations presented in [Billone, 1986]; more detailed calculations necessary). $\|{ }^{\mathrm{c}}$ Calculated with Cheng-Todreas correlation for wire-wrap fuel rods and with Colebrook's correlation for plates (roughness parameter $=10^{-4}$ ). $\|{ }^{\mathrm{d}}$ Lowering the sodium inlet temperature from $350^{\circ} \mathrm{C}$ down to $300^{\circ} \mathrm{C}$ would lower the pressure drop from $0.87 \mathrm{MPa}$ down to $0.55 \mathrm{MPa}$. ${ }^{\mathrm{e}} \mathrm{Low}$ ering the sodium inlet temperature from $350^{\circ} \mathrm{C}$ down to $300^{\circ} \mathrm{C}$ would lower the velocity from $20 \mathrm{~m} / \mathrm{s}$ down to $15 \mathrm{~m} / \mathrm{s}$. $\|{ }^{\mathrm{f}}$ Lowering the sodium inlet temperature from $350^{\circ} \mathrm{C}$ down to $300^{\circ} \mathrm{C}$ would lower the pressure drop from $1.17 \mathrm{MPa}$ down to $0.74 \mathrm{MPa}$.

Fuel thermal margins may be used to increase the $\mathrm{Pu}$ content in the fuel and minimize the need for uranium enrichment. For example, by interpolating between data points presented in INL/EXT-20-57186, it can be inferred that increasing the plutonium content from the reference $20 \%$ up to $27 \%$ would allow for lowering uranium enrichment from $20 \%$ down to about $3.5 \%$. As mentioned earlier, the thermal conductivity and solidus temperature decrease as the $\mathrm{Pu}$ content is increased. For $27 \% \mathrm{Pu}$, [NUREG-1368] recommends using a nominal solidus temperature of about $1000^{\circ} \mathrm{C}$-i.e., $120^{\circ} \mathrm{C}$ lower than with $20 \% \mathrm{Pu}$ - and a thermal conductivity of about $0.09 \mathrm{~W} / \mathrm{cm}$ $\mathrm{K}$-i.e., about $20 \%$ lower than with $20 \% \mathrm{Pu}$. Hence, whereas peak fuel temperatures are $730^{\circ} \mathrm{C}$ and $750^{\circ} \mathrm{C}$ in the $\mathrm{J} 11$ and $\mathrm{K} 11$ assemblies when $\mathrm{U}-20 \mathrm{Pu}-10 \mathrm{Zr}$ is used together with inlet/outlet sodium temperatures of $200 / 425^{\circ} \mathrm{C}$, peak fuel temperatures would increase to about $805^{\circ} \mathrm{C}$ and $830^{\circ} \mathrm{C}$ if $\mathrm{U}-27 \mathrm{Pu}-10 \mathrm{Zr}$ were used. Reducing inlet/outlet temperatures further may be necessary to provide sufficient margins with respect to incipient fuel melting. 


\section{CONCLUSION}

All sodium-cooled fast test reactors operated so far have used essentially the same fuel geometrical arrangement, namely cylindrical fuel pins assembled into a triangular array in hexagonal fuel assemblies. Furthermore, most sodium-cooled reactors have operated, and still operate, with core-average inlet and outlet sodium temperatures of $350-400^{\circ} \mathrm{C}$ and $500-550^{\circ} \mathrm{C}$, respectively. The present preliminary study revisits the standard fuel assembly geometry as well as operating temperatures to evaluate potential impact on peak fast flux.

A 271-pin fuel assembly is considered as a reference and a 397-pin assembly is also considered as a bounding pin configuration. U-20Pu-10Zr driver fuel plates are considered as well as two sets of core-average sodium inlet/outlet temperatures $\left(350 / 500^{\circ} \mathrm{C}\right.$ and $\left.200 / 400^{\circ} \mathrm{C}\right)$. It is noteworthy that structural materials present in the driver fuel assemblies are not expected to accumulate more than 100 dpa over their lifetime. Hence steel alloys that are not suited for very high dpa but can operate over a wide range of temperatures would be appropriate for this application. The sodium-cooled fast test reactor of interest here should reach a peak fast flux that is as high as possible and the core thermal power should not exceed $300 \mathrm{MW}$.

Medium-grade fuel. Assuming a U-20Pu-10Zr fuel using 72\%-fissile reactor-grade plutonium together with 5\% enriched uranium, a $300 \mathrm{MW}$ core containing 66 fuel assemblies (pins or plates) could reach a peak fast flux of $4.4 \times 10^{15} \mathrm{n} / \mathrm{cm}^{2}$-s (i.e., similar to that obtained in the 400-MW Fast Flux Test Facility). All configurations have sufficient margins with respect to the assumed nominal (i.e., w/o uncertainties) fuel temperature and cladding limits of $840^{\circ} \mathrm{C}$ and $580^{\circ} \mathrm{C}$. Hence, with respect to increasing the peak fast flux while maintaining sufficient operational margins, there do not seem to be any strong incentives to favor one configuration over another.

High-grade fuel. Assuming a U-20Pu-10Zr fuel using 94\%-fissile weapons-grade plutonium together with $10 \%$ enriched uranium, a $300 \mathrm{MW}$ core containing 46 fuel assemblies could reach a peak fast flux of $6.1 \times 10^{15} \mathrm{n} / \mathrm{cm}^{2}-\mathrm{s}$. In order to reach this peak fast flux with the reference 271-pin assembly, without exceeding the fuel temperature limit, the core-average sodium inlet/outlet temperatures should be reduced from the reference $350 / 500^{\circ} \mathrm{C}$ down to 200/400 ${ }^{\circ}$ C. With 397-pin assemblies or plate-type assemblies this peak fast flux may be reached for both sets of inlet/outlet temperatures. Assuming 300 EFPD of operation per calendar year, a test article could accumulate up to $80 \mathrm{dpa} /$ year.

Super-high-grade fuel. Assuming a U-20Pu-10Zr fuel using 94\%-fissile weapons-grade plutonium together with $20 \%$ enriched uranium, a $300 \mathrm{MW}$ core containing 29 fuel assemblies could reach a peak fast flux of $7.9 \times 10^{15}$ $\mathrm{n} / \mathrm{cm}^{2}$-s. Using the reference 271-pin assembly it is not possible to reach this peak fast flux without exceeding the fuel temperature limit; however, it may be done with a 397-pin assembly and core-average inlet/outlet sodium temperatures of $200 / 400^{\circ} \mathrm{C}$. With plate-type assemblies this peak fast flux may be reached for both sets of inlet/outlet temperatures. Assuming 300 EFPD of operation per calendar year, a test article could accumulate up to $100 \mathrm{dpa} /$ year.

Everything else being the same - including power density and inlet/outlet sodium temperatures - peak fuel temperatures are lower with plates than with pins. The additional fuel thermal margins provided by plates may be used to increase the plutonium content in the fuel, thus, reducing the need for uranium enrichment or allowing the use of lower quality plutonium ( $\mathrm{U}-\mathrm{xPu}-10 \mathrm{Zr}$ thermal conductivity and solidus temperature decrease as $\mathrm{x}$ increases, hence, necessitating additional thermal margins). For example, for the high-grade fuel, increasing the plutonium content up to about $24 \%$ would allow lowering the uranium enrichment from $10 \%$ down to natural uranium. For the super-high-grade fuel, increasing the plutonium content up to about $27 \%$ would allow for lowering uranium enrichment from $20 \%$ down to about $3.5 \%$.

Finally, because pins and plates assemblies fit on the same grid plate, a sodium-cooled fast test reactor could, in principle, start-up with standard fuel pin assemblies and, later on, move to a plate-type Mark-II fuel to increase the peak fast flux. Confirming the practicality of fuel plate assemblies for sodium-cooled fast test reactors would of course need a significant fuel testing program. 


\section{REFERENCES}

M. C. Billone, Y. Y. Liu, E. E. Gruber, T. H. Hughes, J. M. Kramer, Status of fuel element modeling codes for metallic fuels, International conference on Reliable Fuels for Liquid Metal Reactors, Tucson, Arizona, 1986

A. Amorosi and J. G. Yevick, Fast Reactor Technology: Plant Design, MIT Press (1966)

T. Aoyama, T. Sekine, S. Tabuchi, Characterization of neutron field in the experimental fast reactor JOYO for fuel and structural material irradiation test, Nuclear Engineering and Design Volume 228, Issues 1-3, March 2004.

J. Carmack, K. Barrett, Light Water Reactor Accident Tolerant Fuels Irradiation Testing, TopFuel 2015

V.A. Eliseev, L.V. Korobeynikova, P.A. Maslov, I.V. Malysheva, V.I. Matveev, On feasibility of using nitride and metallic fuel in the MBIR reactor core, Table 3, Nuclear Energy and Technology 2 (2016) 179-182

J. Graham, Fast Reactor Safety, ISBN-978-0-12-294950-0, Academic Press, Inc.,1971

S. B. Grover and R. V. Furstenau, The Advanced Test Reactor Irradiation Facilities and Capabilities, PHYTRA1: First International Conference on Physics and Technology of Reactors and Applications, 2007

F. H. Huang, Comparison of Fracture behavior of low-swelling ferritic and austenitic alloys irradiated in FFTF to 180 dpa, Engineering Fracture Mechanics Vol. 43, No. 5, pp. 733-748, 1992

IAEA-TECDOC-233, Research Reactor Core Conversion from the use of Highly Enriched Uranium to the use of Low Enriched Uranium Fuels Guidebook”, IAEA, Vienna (1980)

INL/EXT-20-57186, Scoping Analysis of Sodium Cooled Fast Spectrum Test Reactor Cores, 2020

A. Klein, Feasibility and Safety Assessment for Advanced Reactor Concepts Using Vented Fuels, NEUP Project \# 11-3097, (2015)

C. E. Lahm, J. F. Koenig, R. G. Pahl, D. L. Porter, D. C. Crawford, Experience with Advanced Driver Fuels in EBR-2, Journal of Nuclear Materials, Volume 204, 2 September 1993, Pages 119-123

C. Lemaignan, Nuclear Materials and Irradiation Effects, Handbook of Nuclear Engineering, Cacuci (Ed), Volume 1 (page 555), 2010

R. R. Matthews et al, Performance and Operation of the Dounreay Fast Reactor, Third United Nations International Conference on the Peaceful Uses of Atomic Energy, 1964

NUREG-1368, Preapplication Safety Evaluation Report for the Power Reactor Innovative Small Module (PRISM) Liquid-Metal Reactor, page B-19 and B-20, (1994)

P. Puthiyavinayagam, Fast Reactor Core Design, Module 1: General Aspects of Fast Reactors (page 15), Joint ICTP/IAEA School on Physics and Technology of Fast Reactors Systems, 2009

J. J. Sienicki and C. Grandy, Irradiation Testing Vehicles for Fast Reactors from Open Test Assemblies to Closed Loops, 2016

US3996100A, Patent \# US 3,996,100, Vented Nuclear Fuel Element, Date: Dec. 7, 1976, Assignee: Hitachi Ltd

US4163689A, Patent \# US 4,163,689, Vented Nuclear Fuel Element, Date: Aug. 7, 1979, Assignee: US Department of Energy

US8929505B2, Patent \# US 8,929,505 B2, Vented Nuclear Fission Fuel Module, Date: Jan. 6, 2015, Assignee: TerraPower, LLC, Bellevue, WA (US)

A.E. Waltar et al., Fast Spectrum Reactors, DOI 10.1007/978-1-4419-9572-8, Springer Science and Business Media, LLC 2012, Appendix A, http://link.springer.com/content/pdf/bbm\%3A978-1-4419-9572-8\%2F1.pdf 


\section{APPENDIX A \\ PRELIMINARY ESTIMATION OF THE FISSION GAS PRESSURE IN THE PLENUM}

- A pin with an 80-cm fuel column contains about $155 \mathrm{~g}$ of UPu which corresponds to about $155 \div 238=0.651$ mole of UPu.

- In a fuel pin characterized by an average burnup of $8 \%$ (corresponding to about $10 \%$ peak burnup), $0.651 \times 0.08$ $=0.0521$ mole of UPu will have undergone fission.

- In a fast neutron reactor, as a first approximation, it can be assumed that 0.23 atom of xenon and 0.02 atom of krypton are produced per fission [Bailly, 1999]. Hence, the pin will contain approximately $0.0521 \times 0.25=0.0130$ mole of fission gas.

- Experiments have shown that about $70 \%$ of the fission gas generated in a $\mathrm{U}-\mathrm{xPu}-10 \mathrm{Zr}$ fuel migrate to the plenum [Porter, 2012]. Hence, the plenum will contain $0.0130 \times 0.70=0.0091$ mole of fission gas (FG).

- The pin plenum length is $80 \mathrm{~cm}$. Assuming that sodium occupies the space up to $7.5 \mathrm{~cm}$ above the fuel ${ }^{\mathbf{a}}$ and that the fuel expands axially by $4 \%$, the plenum length available for FG is approximately $80 \mathrm{~cm}-7.5 \mathrm{~cm}-0.04 * 80$ $\mathrm{cm}=69.3 \mathrm{~cm}$. The plenum volume available for FG is then about $12.6 \mathrm{~cm}^{3}$.

- Assuming that the nominal FG plenum temperature in a hot channel is the same as the sodium temperature, i.e., $550 \mathrm{C}(823 \mathrm{~K})$, pressure can then be estimated as: $\mathrm{P}=\mathrm{Z} \times \mathrm{n} \times \mathrm{R} \times \mathrm{T} \div \mathrm{V}$. Since the plenum temperature is 3 to 4 times higher than the xenon and krypton critical temperatures, the compressibility factor, Z, can to a very good approximation be taken as unity. Hence $\mathrm{P}=1 \times 0.0091 \times 8.314 \times 823 \div 12.6 \times 10^{-6}=4.95 \mathrm{MPa}$.

\section{$\underline{\text { References }}$}

Henri Bailly, Denise Ménessier and Claude Prunier, The Nuclear Fuel of Pressurized Water Reactors and Fast Reactors, page 112, Collection du Commissariat à l'Énergie Atomique, 1999

D.L. Porter, Hanchung Tsai, Full-length $\mathrm{U}-\mathrm{xPu}-10 \mathrm{Zr}(\mathrm{x}=0,8,19$ wt.\%) fast reactor fuel test in FFTF, Journal of Nuclear Materials 427 (2012) 46-57

a The value of $7.5 \mathrm{~cm}$ is obtained by assuming that the initial sodium level is $1.5 \mathrm{~cm}$ above the top of the fuel column and that $30 \%$ of the bond sodium is pushed in the plenum as the fuel expands (i.e. $80 \mathrm{~cm} \times 0.25 \times 0.3=6 \mathrm{~cm}$ ). 


\title{
APPENDIX B \\ PRELIMINARY ESTIMATION OF THE IMPACT OF SPACERS ON PLATE DEFORMATION DUE TO FISSION GAS PRESSURIZATION
}

\author{
Hakan Ozaltun
}

Using simplified two-plate two-dimensional models, the Abaqus software was used to evaluate cladding stresses and deformation resulting from $5 \mathrm{MPa}$ internal fission gas pressure and $0.2 \mathrm{MPa}$ external coolant pressure. Three, then seven, I-shaped spacers were modeled in the coolant channels. Plate width, cladding thickness, and coolant channel thickness are $62.35 \mathrm{~mm}, 0.39 \mathrm{~mm}$, and $1.73 \mathrm{~mm}$, respectively. These preliminary results indicate that the use of three spacers would lead to excessive plate deformation, whereas, with seven spacers it would be negligible. These results are preliminary and more detailed analyses would be necessary to confirm this important conclusion.
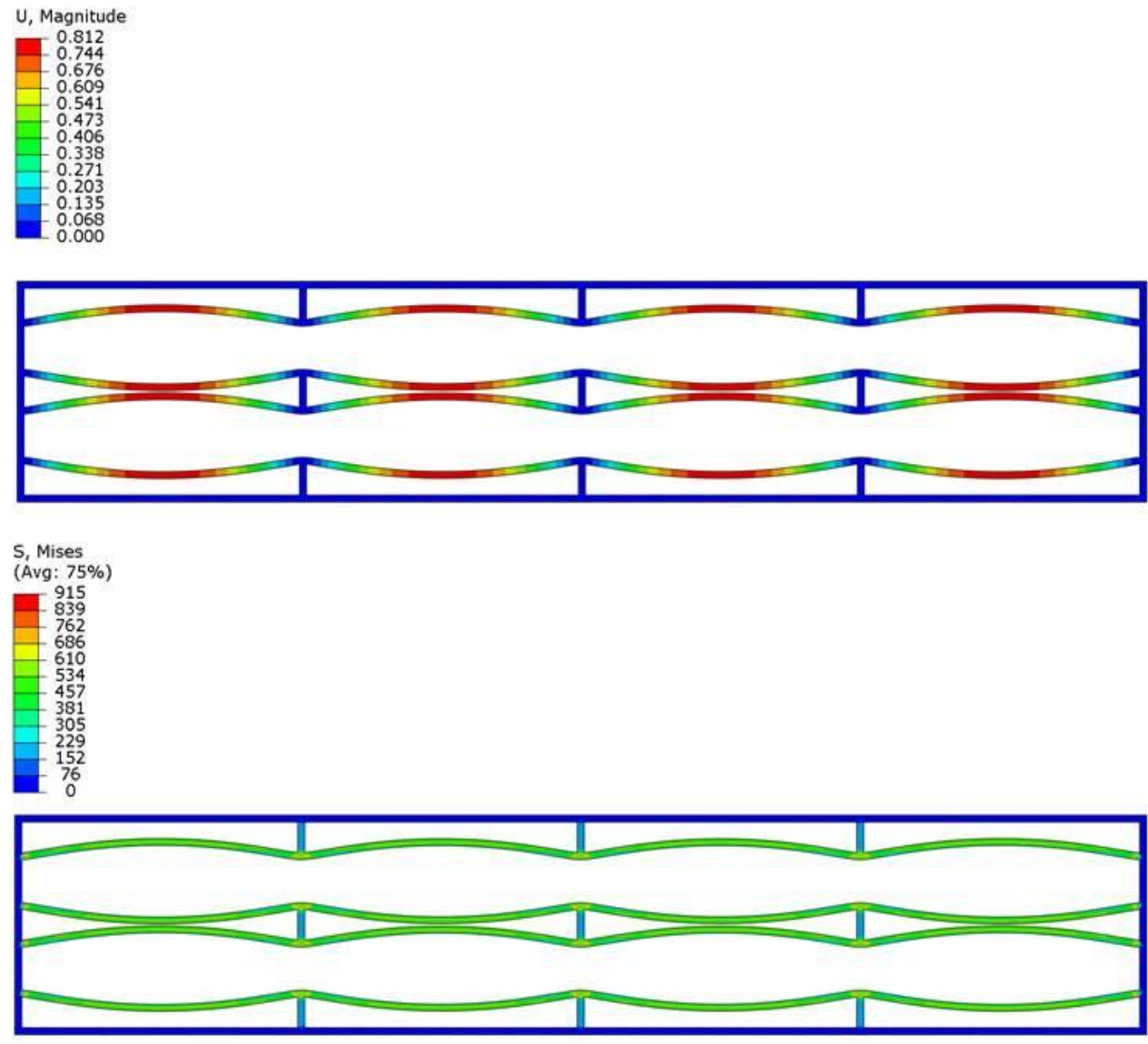

Deformation (mm)

3 Spacers

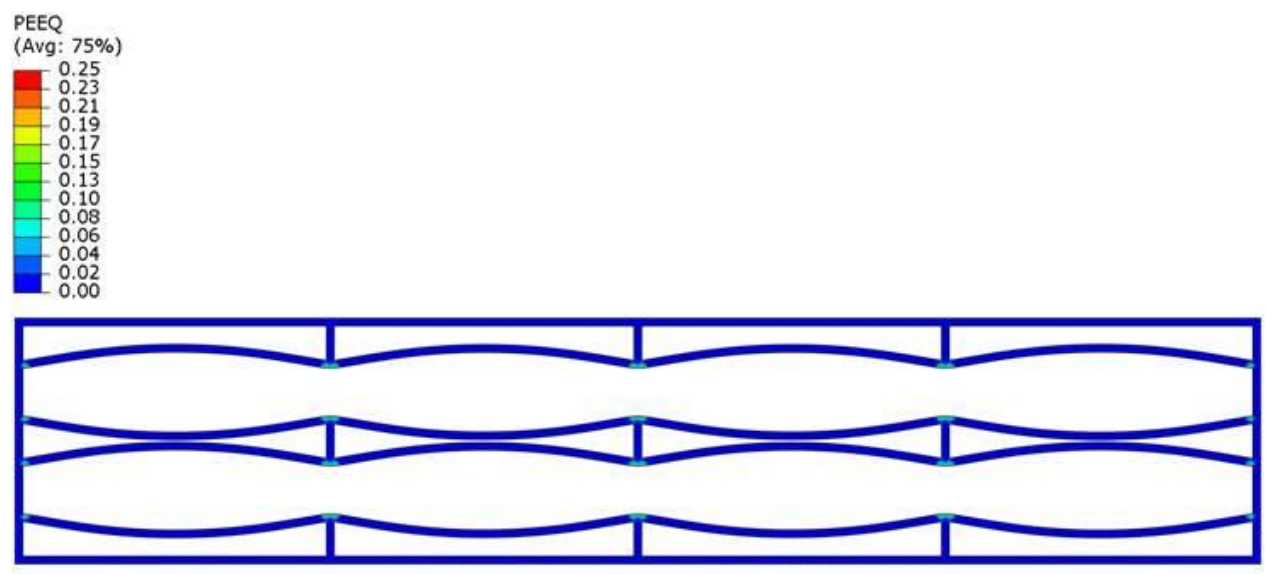

Von Mises Stresses

(MPa)

3 Spacers

Equivalent Plastic

Strains

3 Spacers 


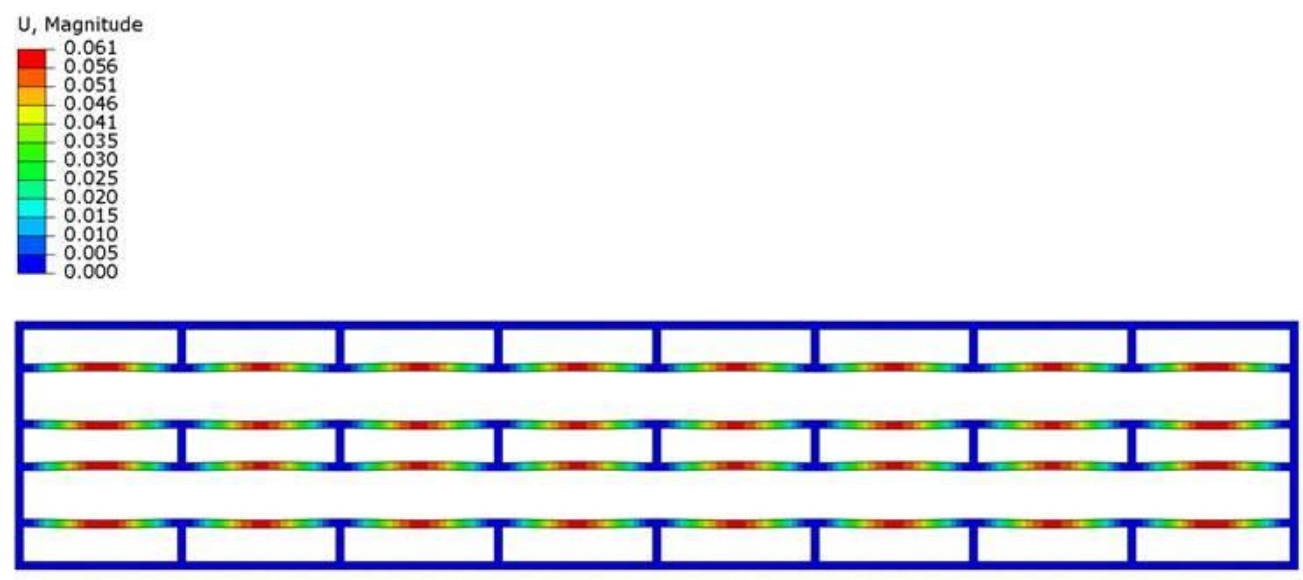

Deformation (mm)

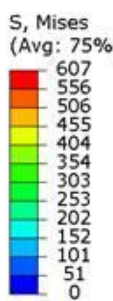

7 Spacers

Von Mises Stresses (MPa)

7 Spacers
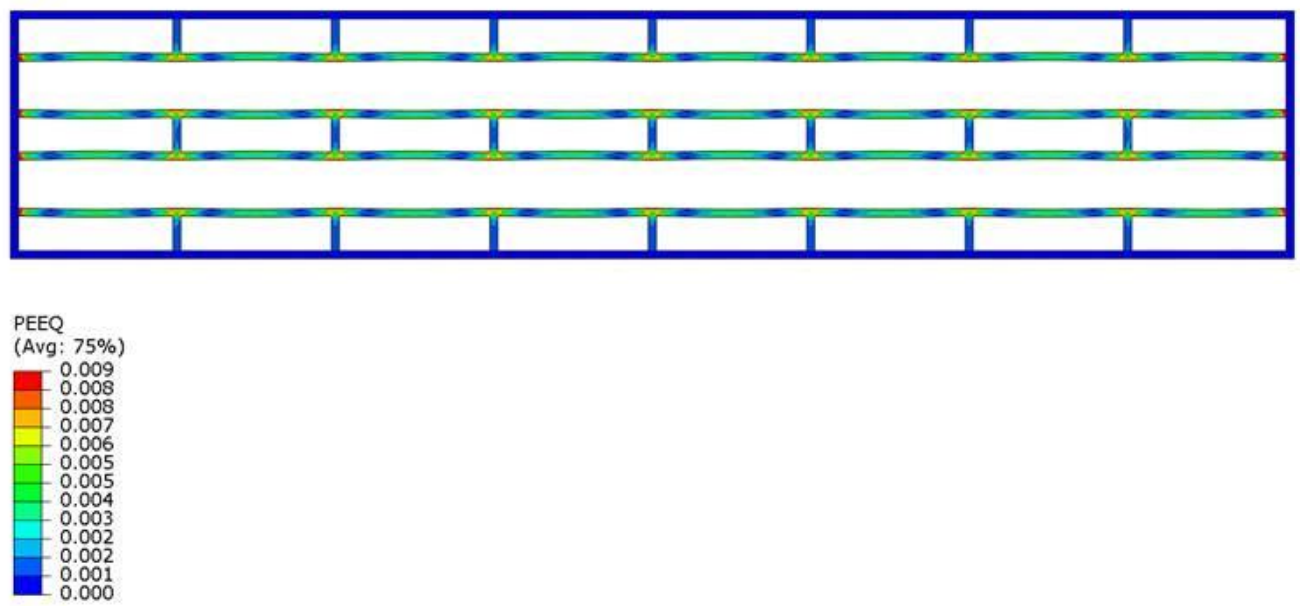

Equivalent Plastic

Strains

7 Spacers

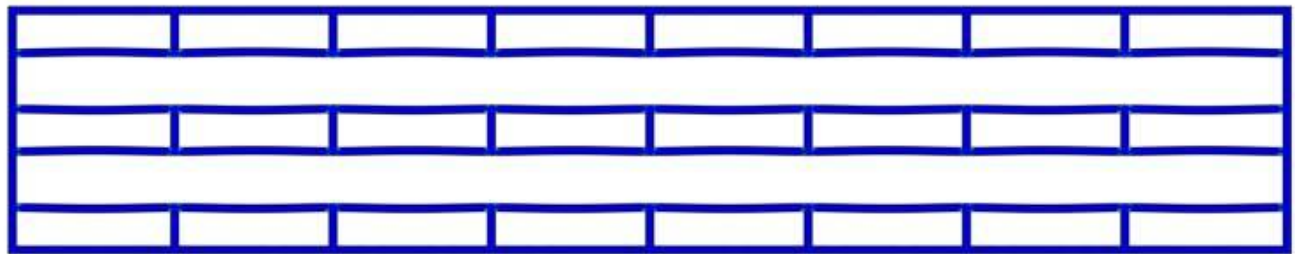

